\title{
GEODYNAMICAL STUDIES IN THE NEAR EAST MEDITERRANEAN AND RED SEA REGION USING GPS AND SEISMOLOGICAL DATA ANALYSIS
}

\author{
By
}

*H. Khalil, **M. Becker, *Abdel-Monem S.M, *K, Sakr, *S. Mahmoud, *H. Hussain, Abou El Einen, *Ali K. Abdel-Fattah, ***A. Al Aydros and *Aly Rayan

The Research work deals with Kinematics and Dynamics of the active areas in the Near East Mediterranean and Red Sea regions and extends to the Southern part of the Red Sea to include the major territories of Yemen. The prototype of the Red Sea as a classical continental rifting is focused to show its spreading. The collaborative effort is extended to use Global Positioning System (GPS) observations to measure directly the present-day style and rates of extension and rift-margin deformation along the extent of the Red Sea rift and the northern part of Africa versus Europe mainly, the Near East

National Research Institute of Astronomy and Geophysics, Helwan, Cairo, Egypt.

** Institute of Geodesy, UBW, Munich.

*** Faculty of Science, Sanaa University. 
Mediterranean. The field observations comprise measurements of GPS campaigns, Apr., 2000, Oct., 2001 and Dec., 2003, through a geodetic networks in Egypt and Yemen beside the IGS permanent stations around the study regions. We used GPS constraints on present-day deformation with available seismological data analysis for understanding and threw lights upon the geodynamical regime of the study regions.

\section{Introduction}

The subject of the research is dealing with the use of GPS and seismological data for the investigation of recent crustal kinematics for geodynamical studies on the seismo-active areas in the Near East Mediterranean and Red Sea regions.

The seismological data were used for processing the focal mechanism solutions as a combined solution. Bernese V.4.2 Software was used, among other facilities of the available GPS and seismological data in the area.

The independence of Recent Crustal Movements Laboratory (NRIAG in Egypt) has introduced in the last few years the technology of the Global Positioning System (GPS) for observing and detecting the crustal deformations in the seismo-active areas in Egypt through the geodetic networks, e.g. Sinai, Red Sea, Middle of Upper Egypt and around Nasser Lake at Aswan. Thus, the plan of study has been developed for global measurements through the international cooperation between NRIAG and Sana'a University through an established GPS geodetic network includes some geodetic points in Yemen and another in Egypt. Three GPS campaigns between Egypt and Yemen were measured in Apr., 2000, Oct., 2001 and Dec., 2003 respectively. The analysis processes of GPS and the seismological data played a great role for understanding and threw lights upon the geodynamical regime of the area and to evaluate a general framework of the study regions. 


\section{Applied Techniques}

\section{A) GPS Measurements}

For the evaluation of the observed Yemen-Egypt GPS geodetic network in 2000, 2001 and 2003; a combination from selected IGS stations was set up with five sites in Yemen and five sites in Egypt. Figure (1) shows the IGS sites WTZR, MATE, RAMO, AMMN, BAHR, IISC and MALI which were analyzed through the observed campaigns. The IGS sites serve as anchor stations to tie the regional network to the International Terrestrial Reference Frame ITRF 2000. Figure (1) includes also the configuration of the GPS geodetic network Yemen-Egypt. Figure (2) shows the sites of some established geodetic points in Yemen.

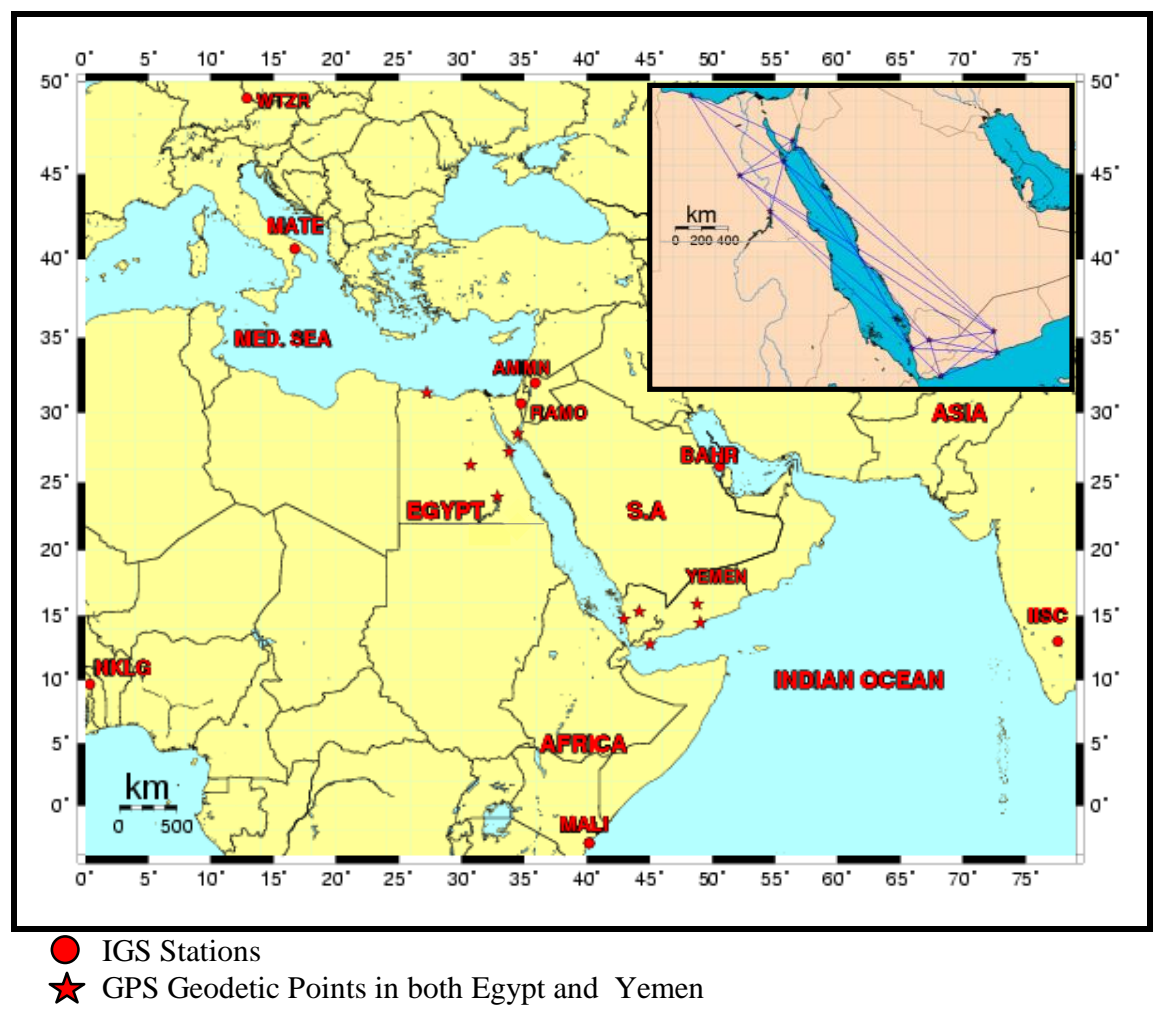

Fig. (1) : Shows the points of Egypt-Yemen GPS Geodetic Network. 

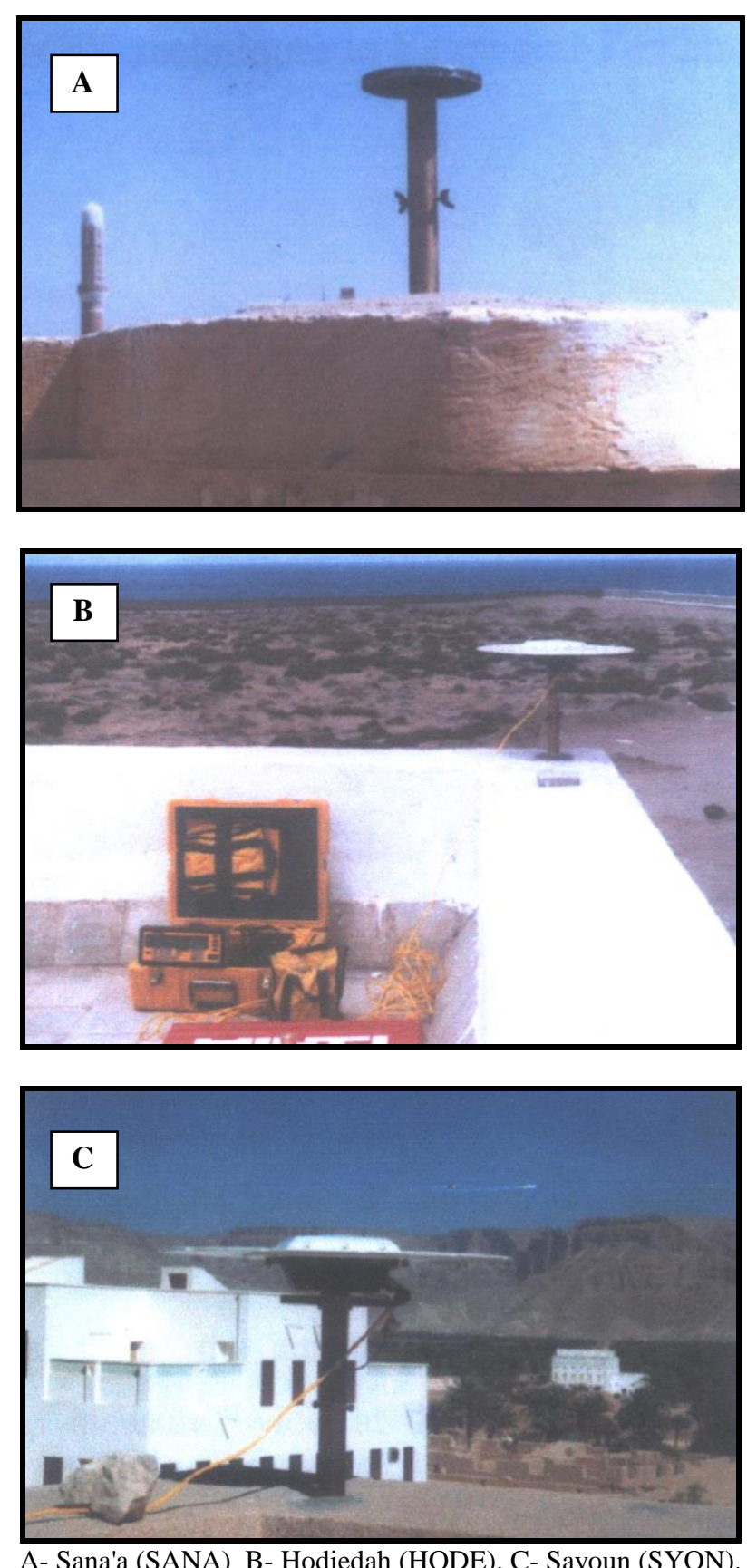

Fig. (2): Shows the Locations of some GPS stations in Yemen. -12 - 
Using of this combination not only the deformation within the network could be detected but also the motion components in the ITRF 2000 directly are obtained. The three campaigns were evaluated following the standards for high quality reference frame GPS works as described (Matthias, 2002). Results of an Ionosphere-free L3 solution are derived from all sessions in each epoch and saved as an epoch solution. The loose solutions of each epoch were combined and constraint by the motions of the IGS anchor sites in the ITRF 2000 reference frame.

GPS and other new techniques are used to study ground deformation associated with earthquakes. Our study focuses on combining GPS data from a geodetic network and focal mechanisms deduced from the seismological data analysis considering some previous studies which were carried out in the study region beside the analysis and interpretation which carried out by our team. The dealing of GPS Data analysis will be portrayed after the discussion of the seismological data analysis

\section{B) Focal Mechanism}

It is well known that most earthquake occurrences are due to a sudden rupture taking place along faults in the earth. Some of these faults have a surface rupture associated with the earthquake. As most of the fault ruptures of earthquakes do not reach the earth surface and is thus not directly visible. Seismological approaches such as the focal mechanism study are indispensable for studying seismic faults and their rupture process, the focal mechanism bears information not only on seismic faults, but also on the tectonics around the earthquake source region, plate motion and the tectonic stress which causes the earthquake. Plate motions on the earth surface are now inferred from slip vectors of fault plane solutions obtained for a large number of earthquakes over the world. The seismic fault model of earthquakes is based on the analysis of seismic waves. 


\section{i. Seismicity and Focal Mechanisms of the Near East African Margin}

The earthquake activity of this margin is related to shelf and continental slope extending from the shelf break down to the Nile cone. It is more or less parallel to the Egyptian shore. It extends from Cyrenaica (Eastern Libya) to the northern part of Sinai. Some authors (Sofratome Group, 1984; Ben-Avraham et al., 1987) indicated that the continental margin can be considered as a weakness zone having experienced thinning during the Triassic period. This transition zone between the faulted continental and oceanic crusts might be predestined in $\mathrm{N} 110^{\circ}-120^{\circ} \mathrm{E}$ orientation and to be reactivated with dextral strike slip and reverse fault component. Figure (3) shows the relative seismic activities in the northern part of the study region. This part is diffuse and do not constitute any lineaments which may be restricted to the accuracy of data specially for this part because it is far from both Egyptian stations and European stations. A cluster of the seismic activity is clearly shown along the northeastern part of Libya (Cyrenaica) which represent the closest area to the subduction process beneath Hellenic arc. Few larger events are located along the Egyptian coastal shelf. The focal mechanisms of larger events along this margin reflect a transition from a tensional stress to the south of the continental shelf to compressional stress to the south of the subduction zone (Fig. 4).

\section{ii. Seismicity and Focal Mechanisms of the Hellenic Arc:}

The shallow earthquake activity $(\mathrm{h}<60 \mathrm{~km})$ is contained in a belt parallel to the Hellenic and Cyprean arcs (Fig. 3). The rate of activity is higher in the Hellenic arc than in the Cyprean arc. The activity of the Hellenic arc extends from Albania in the West to Eastern Turkey in the East. The activity is mostly seaward of the islands and all large events occur between the deepest part of the trench and islands. Few shocks lie as far as the Mediterranean ridge and the swell south of the deep basins. 


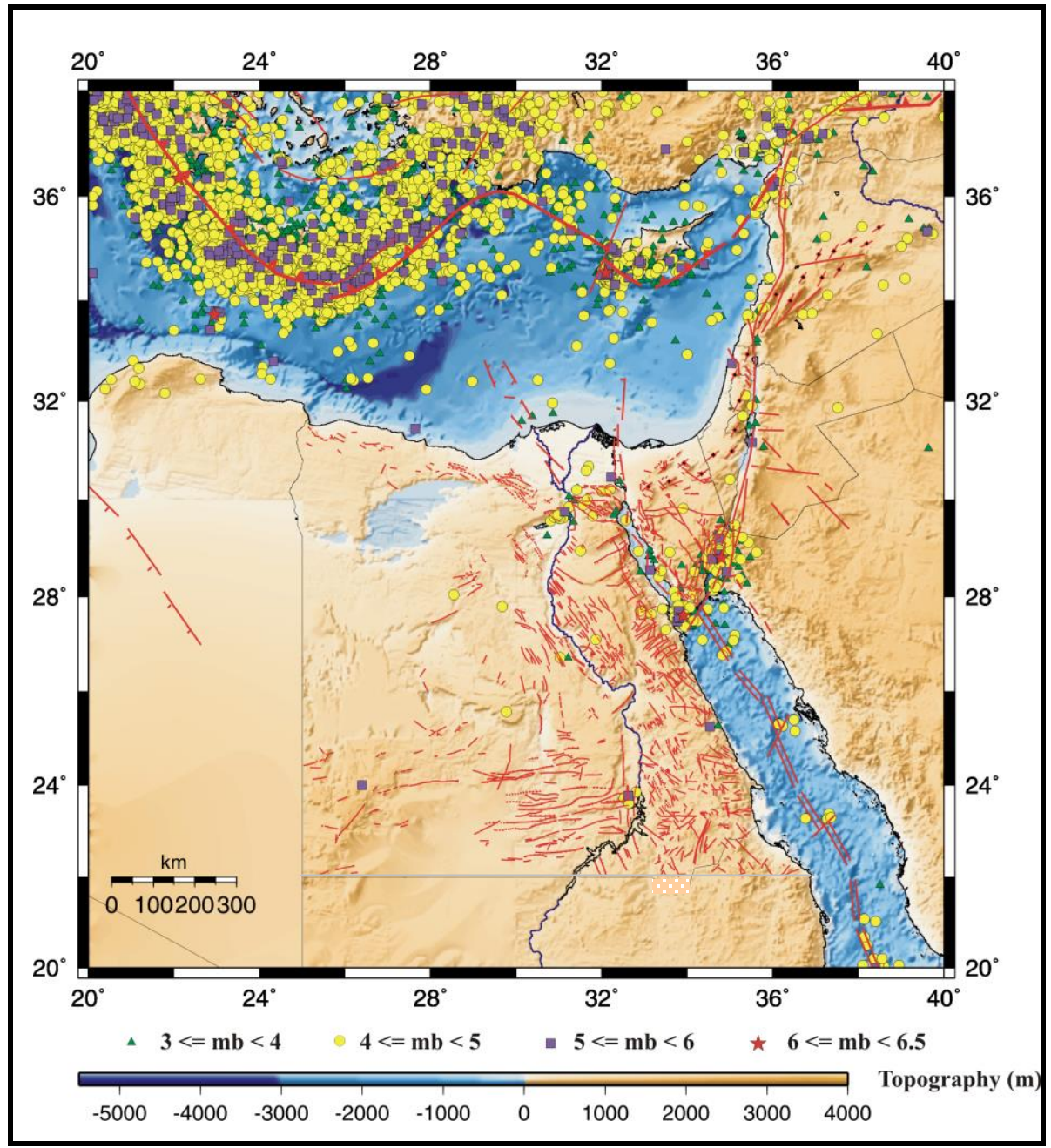

Fig. (3): Seismicity map of the East Mediterranean Regionn from 1964-2003 (ISC) Data. and Regional tectonic setting. A compiled map from Sofratome Group (1984), Abou Elenean (1997), Reilinger et al., (2000), Egyptian Geological Survey (1981) and Salamon et al., (1996). 


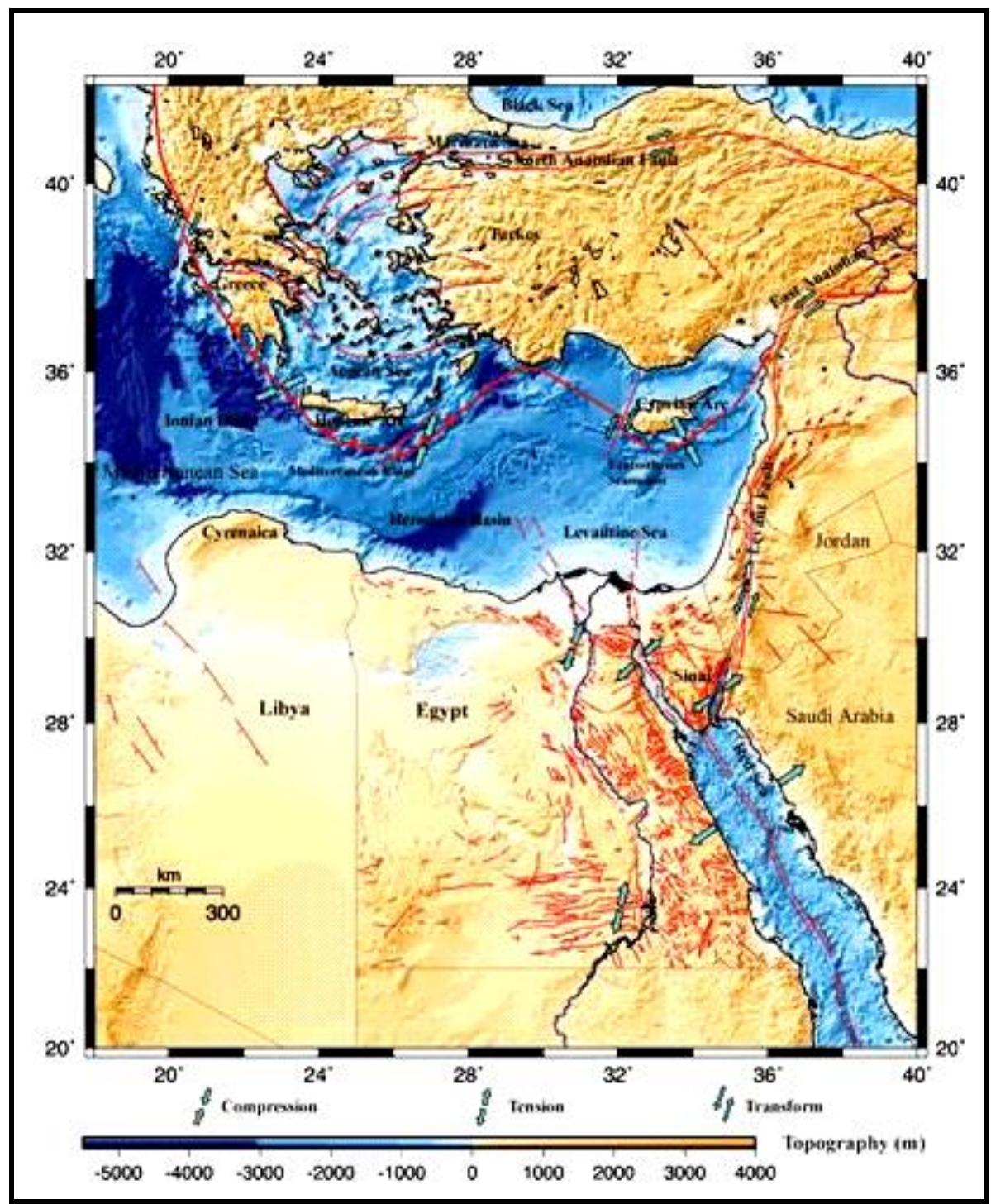

Fig. (4): Regional tectonic setting of the Eastern Mediterranean Region. A compiled map from Sofratome Group (1984), Abou Elenean (1997), Reilinger et al., (2000), Egyptian Geological Survey (1981) and Salamon et al., (1996). 
There is a low activity to the north of the arc, hence the southern part of the Aegean sea is moving as a relatively rigid block when compared with the surrounding zones (McKenzie, 1978). The seismicity of the Eastern Hellenic arc is more diffusing and higher than the Western Hellenic arc, which may be due to a seismic gap or the activity of the arcs which depends on the thickness of sediments on the top of the subducted plate.

The spatial distribution of the earthquake hypocenters $(60<\mathrm{h}$ $<300 \mathrm{~km}$ ) on the Hellenic arc (Korrat et al., 1996) indicates that, the subduction of the African plate under the Eurasian plate took place at an angle of about $30^{\circ}$ and reaches a maximum depth of about $200 \mathrm{~km}$.

The focal mechanisms of shallower earthquakes (Table.1) occurred in the convex side of Hellenic arc show a pure reverse faults and reverse faults with strike slip components (Fig. 4). The main trend of P-axis is in SW-NE direction (Figs. 5 and 6), which is almost perpendicular to the arc in its northwestern part but tends to become parallel to it in its southeastern part. The focal mechanisms for some events, which occur either in the convex side or in the concave side, show normal faults or normal faults with strike slip component. The trend of T-axis for these events takes the same direction of the dipping slab in western Hellenic arc and rotates to become in NW-SE direction in eastern Hellenic arc. Papadopoulos et al. (1986) explained the occurrence of these events in the convex side due to bending down of the subducted slab. In the western Hellenic arc most of the movement is approximately down dip movement with the dip angle increasing with the depth of events (Korrat et al., 1996), while in eastern Hellenic the strike slip movement increased. This phenomenon is probably due to the rotation of southwestern Turkey. The dominant focal mechanisms of the concave side of the arc are normal faulting which is related to the extensional stress field due to the back arc activity behind the arc, (Figs. 5 and 6). Figure (7) shows the stress tensor directions of the Hellenic arc. 


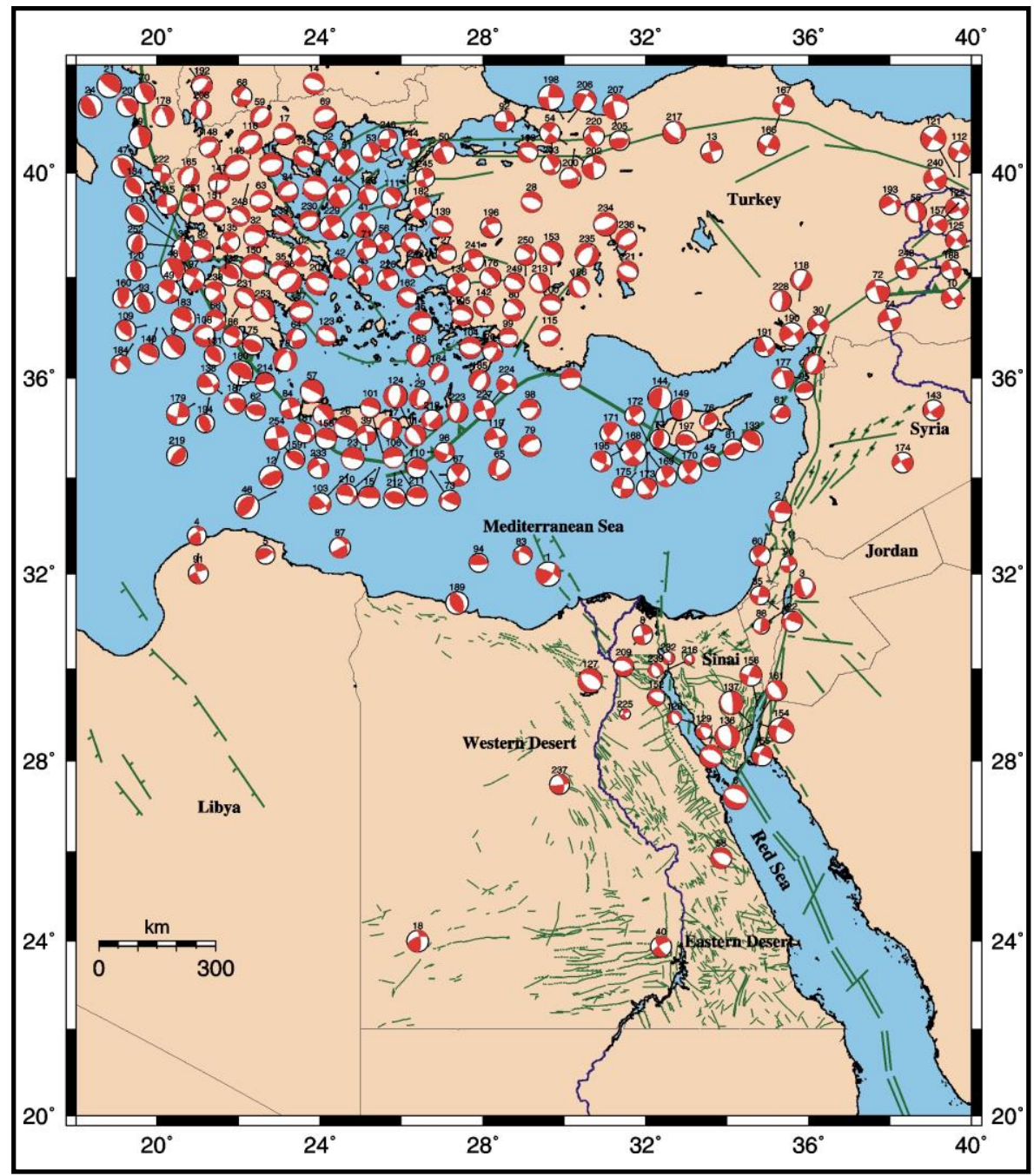

Fig. (5): Focal mechanisms for shallow earthquakes in the Eastern Mediterranean and the northern red Sea Regions ( $\mathrm{h}<60 \mathrm{~km}$ ). Red quadrant denotes compression. 


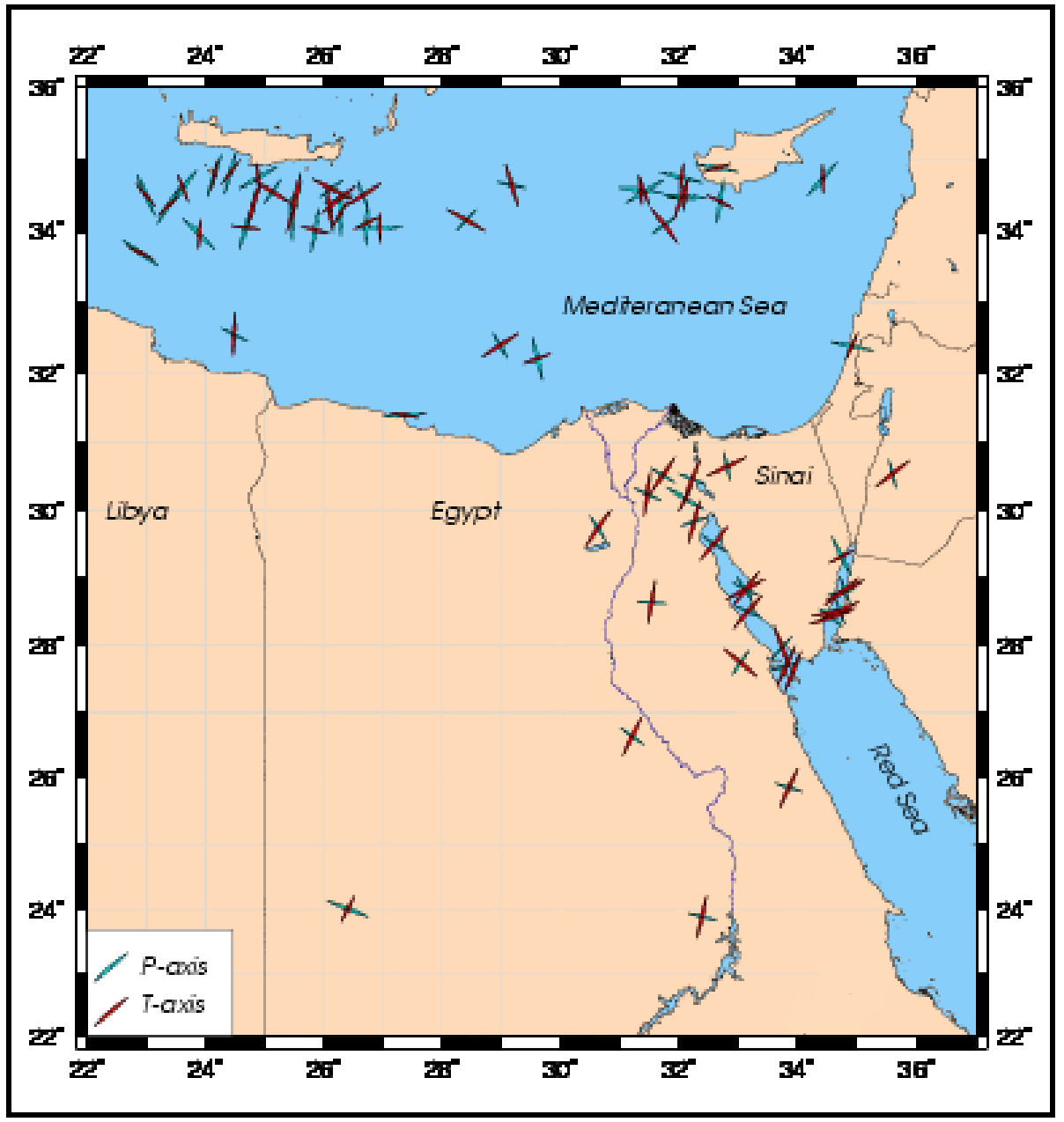

Fig. (6): Spatial Distribution of the Stress Axes Derived from the Focal Mechanisms of Moderate to large Earthquakes. Symbol Length is proportional to the dominant one. 


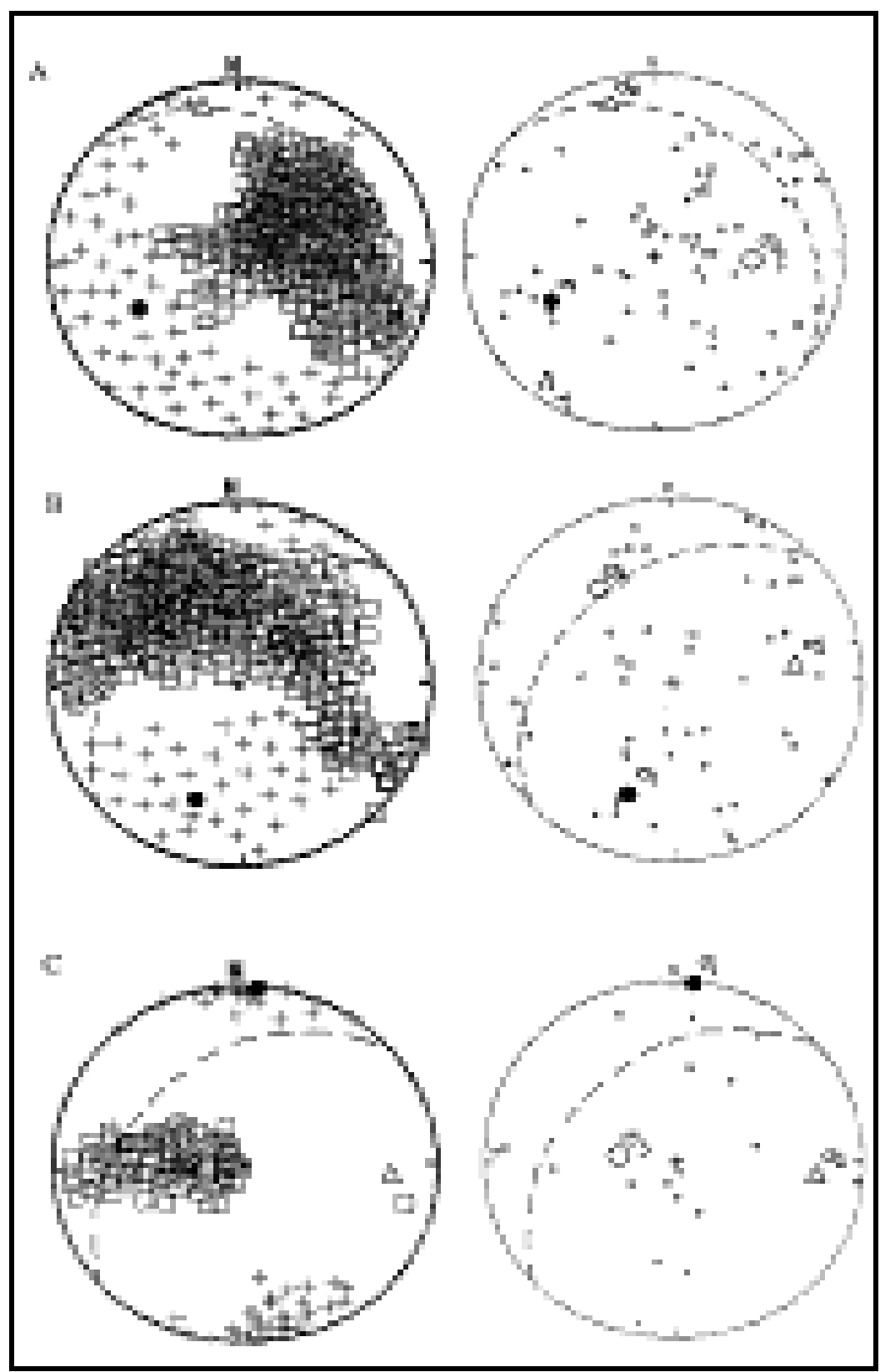

Fig. (7): Stress Tensor Directions of the Hellenic Wadatic-Benioff Zone projected onto a lower Hemisphere for western flank (A), eastern flank (B) and lower part of the eastern flank $(\mathrm{C})$. 


\section{iii. Seismicity and Focal Mechanisms of the Cyprian Arc}

Seismic activity along this arc occurs in a wide seismogenic belt, which suggests that the plate border is a zone of deformation instead of single line. The seismicity follows the arcuate pattern of the arc (Fig. 3). Most of the seismic activity took place in southern Cyprus, few of them occurred in the NW direction and very few in the NE of it. McKenzie (1970, 1972) concluded from a regional earthquake analysis that convergence took place in a north-south direction along most of the Cyprean arc and suggested that a left lateral motion could take place along its easternmost segment curving towards northeast. A continuous zone of seismicity can be traced from Cyprus into Zagros Mountain together with the subparallel seismic zone in Syria (Rotstein and Ben-Avraham, 1985). They also suggested that the lower level of recent and historical (Ambraseys, 1978) seismicity in the easternmost Mediterranean may represent a seismicity gap. This gap will eventually be filled and this gap can be explained by a plate configuration, which will require only a small motion across this segment of the plate boundary.

The seismic activity of southern Cyprus are relatively shallow and may not exceed $100 \mathrm{Km}$. The occurrence of earthquakes deeper than $100 \mathrm{Km}$ prompted to suggest a zone of subduction in this region (McKenzie, 1972). Papazachos and Comninakis (1978) suggested that the pattern of seismicity west of Cyprus is continuous and that a Benioff zone dipping to the north exists across the entire Eastern Mediterranean.

Rotstein and Ben-Avraham (1985) drew three cross sections for the intermediate seismicity of the Levantine basin, two of which are in the Gulf of Antalya and are nearly perpendicular to each other and one across Cyprus. The depth of the observed seismic activity increases from Cyprus to the Gulf of Antalya and dip approximately northwards indicating a simple subduction process in agreement with Buyukasikoglu (1980). The maximum depth of the subducted lithosphere reaches about $80-100 \mathrm{Km}$ in central Cyprus but it is deeper than $100 \mathrm{Km}$ beneath central Anatolia. The subduction zone in central 
Cyprus dips to the NNW with an angle about $25^{\circ}-30^{\circ}$ similar to the Hellenic arc. Rotstein and Ben-Avraham (1985) interpreted the deep seismicity in the Gulf of Antalya to an earlier subduction, which was active prior to the collision of the Anaximander block and continues to be active today.

The Cyprian arc is generally characterized by thrusts and shear mechanisms, with one of their nodal planes being sub-parallel to the strike of the arc (Salamon et al, 2003). Many of the events with shear mechanisms are located southwest of Cyprus. East of Cyprus towards the northern Mediterranean triple junction show both tension and compression with shear component. The Focal mechanisms of few events in Southern Cyprus show either reverse faults or reverse faults with small strike slip components (Abou Elenean, 1993). The direction of the P-axis is NW-SE, which is perpendicular to the arc in its eastern and central parts, but oblique to its western part. The focal mechanisms (Table 1) of some events (Figs. 5 and 6), located in the western part of the Cyprian arc, show strike slip faults with small reverse or normal components. The two nodal planes are trending NNW- SSE and NE-SW. The stress tensor analysis for the Cyprian Arc earthquakes indicates to NW-SE trending P-axis, (Fig. 8).

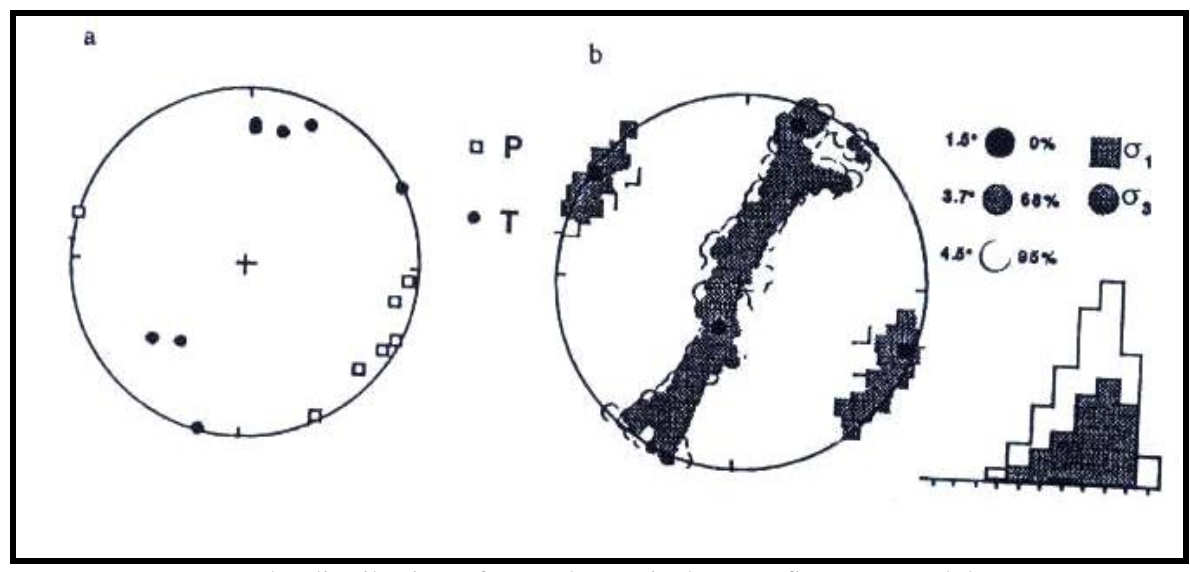

a- The distribution of P- and T- axis b- Best fit stress model.

Fig. (8): The best fit stress model for the Cyperian arc. 
Table (1): Focal mechanism parameters of moderate to large shallow earthquakes occurred recently in the Eastern Mediterranean region.

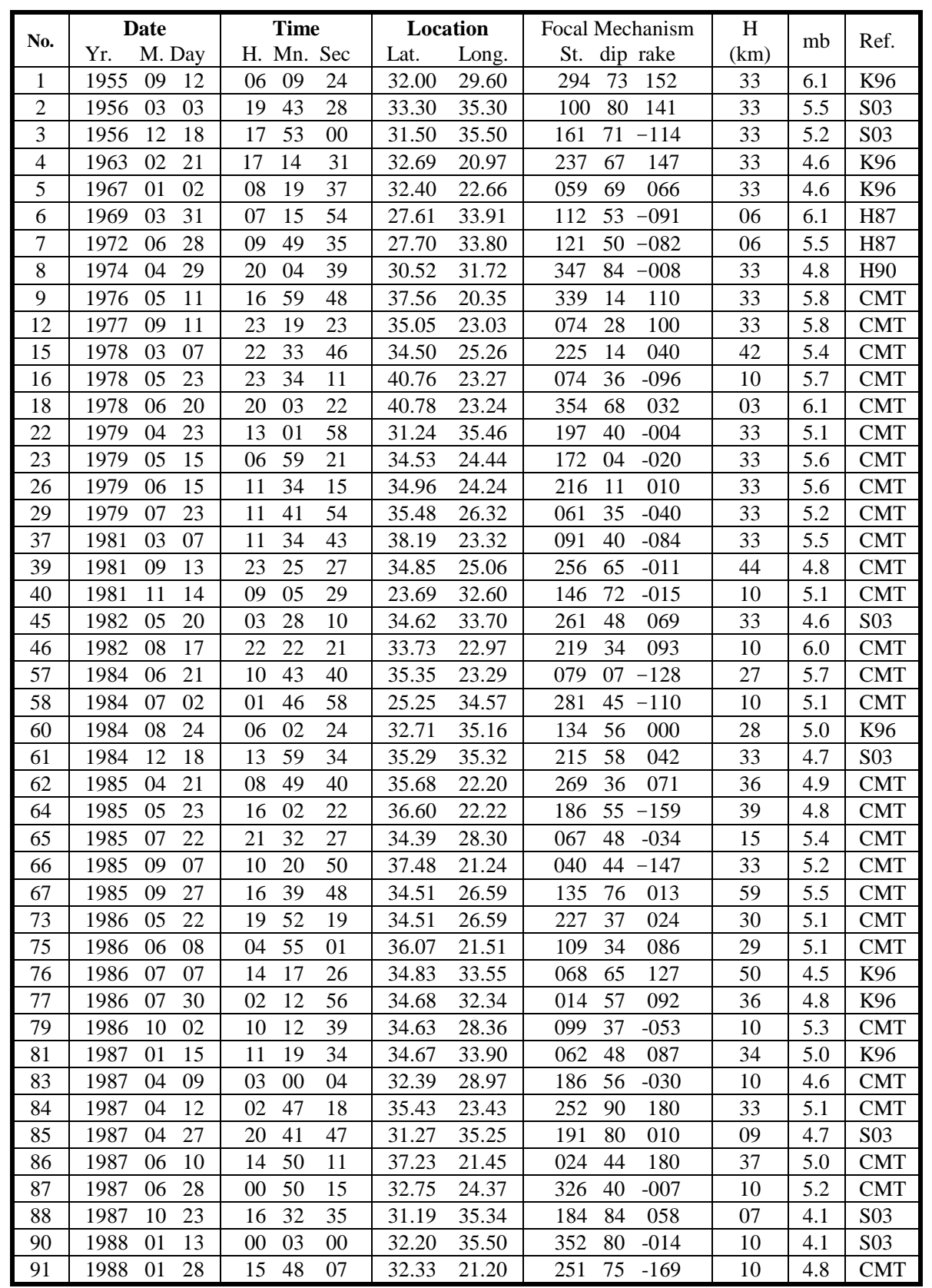


Table (1): Continue.

\begin{tabular}{|c|c|c|c|c|c|c|c|c|c|}
\hline \multirow{2}{*}{$\begin{array}{l}\text { No. } \\
93 \\
\end{array}$} & \begin{tabular}{ll}
\multicolumn{2}{c}{ Date } \\
Yr. $\quad$ M. Day \\
\end{tabular} & \multicolumn{2}{|c|}{\begin{tabular}{ll}
\multicolumn{1}{c}{ Time } \\
H. Mn. Sec \\
\end{tabular}} & \multicolumn{2}{|c|}{\begin{tabular}{c}
\multicolumn{2}{c}{ Location } \\
Lat. $\quad$ Long. \\
\end{tabular}} & $\begin{array}{c}\text { Focal Mechanism } \\
\text { St. dip rake } \\
\end{array}$ & \multirow{2}{*}{$\begin{array}{c}\begin{array}{c}\mathbf{H} \\
(\mathbf{k m})\end{array} \\
32 \\
\end{array}$} & \multirow{2}{*}{$\begin{array}{c}\mathbf{m b} \\
5.3 \\
\end{array}$} & \multirow{2}{*}{$\begin{array}{l}\text { Ref. } \\
\text { CMT }\end{array}$} \\
\hline & $\begin{array}{lll}1988 & 05 & 18 \\
\end{array}$ & $05 \quad 17$ & 43 & 38.42 & 20.47 & $\begin{array}{lll}163 & 38 & 095 \\
\end{array}$ & & & \\
\hline 94 & $\begin{array}{lll}1988 & 06 & 09 \\
\end{array}$ & $02 \quad 18$ & 24 & 32.23 & 27.90 & $\begin{array}{lll}087 & 71 & 077 \\
\end{array}$ & 10 & 4.7 & CMT \\
\hline 96 & $\begin{array}{lll}1988 & 09 & 05 \\
\end{array}$ & $20 \quad 03$ & 25 & 34.51 & 26.65 & $\begin{array}{lll}015 & 55 & -011 \\
\end{array}$ & 12 & 4.9 & CMT \\
\hline 98 & 1120 & 2101 & 05 & 35.29 & 28.67 & $\begin{array}{llll}024 & 32 & -152 \\
\end{array}$ & 10 & 5.2 & CMT \\
\hline 101 & $03 \quad 17$ & $05 \quad 42$ & 51 & 34.64 & 25.59 & $\begin{array}{lll}077 & 10 & -118 \\
\end{array}$ & 17 & 4.8 & CMT \\
\hline 103 & $03 \quad 28$ & $13 \quad 29$ & 11 & 34.06 & 24.68 & $\begin{array}{lll}067 & 53 & 029 \\
\end{array}$ & 33 & 5.4 & CMT \\
\hline 106 & $06 \quad 14$ & $18 \quad 06$ & 37 & 34.30 & 26.10 & $\begin{array}{lll}102 & 08 & -068 \\
\end{array}$ & 10 & 5.1 & CMT \\
\hline 108 & $08 \quad 20$ & $18 \quad 32$ & 30 & 37.28 & 21.21 & $237 \quad 37 \quad-130$ & 16 & 5.4 & CMT \\
\hline 109 & $08 \quad 24$ & $02 \quad 13$ & 13 & 37.96 & 20.21 & $\begin{array}{lll}356 & 38 & 131 \\
\end{array}$ & 16 & 5.0 & CMT \\
\hline 110 & $08 \quad 27$ & $01 \quad 21$ & 17 & 34.92 & 26.26 & $\begin{array}{lll}223 & 19 & 033 \\
\end{array}$ & 60 & 5.0 & CMT \\
\hline 114 & $\begin{array}{ll}07 \quad 09 \\
\end{array}$ & $11 \quad 22$ & 17 & 34.92 & 26.75 & $129 \quad 27 \quad-106$ & 33 & 5.1 & CMT \\
\hline 117 & $03 \quad 19$ & $12 \quad 09$ & 24 & 34.82 & 26.28 & $245 \quad 36 \quad-033$ & 18 & 5.4 & CMT \\
\hline 119 & 1018 & $14 \quad 04$ & 54 & 35.76 & 28.64 & $\begin{array}{lll}341 & 73 & 177\end{array}$ & 33 & 5.3 & CMT \\
\hline 124 & $04 \quad 30$ & 1144 & 38 & 35.07 & 26.71 & $172 \quad 38-106$ & 17 & 5.7 & CMT \\
\hline 125 & $05 \quad 07$ & $19 \quad 15$ & 02 & 38.68 & 40.13 & $310 \quad 90 \quad-180$ & 10 & 5.0 & CMT \\
\hline 126 & $07 \quad 23$ & $20 \quad 12$ & 42 & 39.82 & 24.39 & $267 \quad 41 \quad-160$ & 07 & 4.9 & CMT \\
\hline 127 & $10 \quad 12$ & 1309 & 56 & 29.89 & 31.22 & $\begin{array}{lll}136 & 42 & -075 \\
\end{array}$ & 25 & 5.9 & A97 \\
\hline 128 & $10 \quad 27$ & $\begin{array}{ll}09 & 04 \\
\end{array}$ & 46 & 28.84 & 33.11 & $\begin{array}{lll}171 & 51 & -063 \\
\end{array}$ & 10 & 3.4 & A97 \\
\hline 129 & $10 \quad 27$ & $11 \quad 02$ & 44 & 28.85 & 33.12 & $\begin{array}{llll}158 & 66 & -046 \\
\end{array}$ & 19 & 3.9 & CMT \\
\hline 131 & $03 \quad 05$ & $06 \quad 55$ & 08 & 37.15 & 21.44 & $\begin{array}{lll}342 & 42 & 120 \\
\end{array}$ & 37 & 5.2 & CMT \\
\hline 133 & $03 \quad 22$ & 1103 & 40 & 34.74 & 34.41 & $\begin{array}{lll}343 & 27 & 133 \\
\end{array}$ & 10 & 5.3 & CMT \\
\hline 136 & $08 \quad 03$ & 1243 & 04 & 28.63 & 34.64 & $139 \quad 36-122$ & 10 & 6.0 & CMT \\
\hline 137 & $08 \quad 03$ & $16 \quad 33$ & 20 & 28.76 & 34.70 & $142 \quad 13 \quad-123$ & 10 & 5.7 & CMT \\
\hline 138 & $01 \quad 11$ & $07 \quad 22$ & 51 & 35.95 & 21.91 & $\begin{array}{lll}077 & 61 & 030 \\
\end{array}$ & 33 & 5.3 & CMT \\
\hline 140 & $04 \quad 16$ & 2309 & 33 & 37.44 & 20.58 & $\begin{array}{lll}340 & 18 & 134 \\
\end{array}$ & 23 & 5.2 & CMT \\
\hline 144 & $02 \quad 23$ & 2103 & 02 & 35.04 & 32.27 & $\begin{array}{lll}239 & 21 & 140\end{array}$ & 15 & 5.8 & CMT \\
\hline 149 & $05 \quad 29$ & $04 \quad 58$ & 32 & 35.06 & 32.26 & $224 \quad 20 \quad 132$ & 10 & 5.3 & CMT \\
\hline 152 & $\begin{array}{ll}09 \quad 08 \\
\end{array}$ & $12 \quad 13$ & 22 & 29.48 & 32.25 & $123 \quad 65-065$ & 13 & 4.2 & A97 \\
\hline 154 & $11 \quad 22$ & $04 \quad 15$ & 11 & 28.82 & 34.86 & $196 \quad 59 \quad-015$ & 10 & 6.2 & CMT \\
\hline 155 & 1122 & $22 \quad 16$ & 53 & 28.45 & 34.84 & $202 \quad 67 \quad-003$ & 10 & 5.0 & CMT \\
\hline 156 & 1123 & $18 \quad 07$ & 17 & 29.25 & 34.64 & $\begin{array}{lll}199 & 77 & 007\end{array}$ & 10 & 5.3 & CMT \\
\hline 158 & $12 \quad 07$ & $18 \quad 00$ & 50 & 34.79 & 24.15 & $319 \quad 06 \quad 123$ & 00 & 5.2 & CMT \\
\hline 160 & $\begin{array}{ll}02 & 01 \\
\end{array}$ & $17 \quad 57$ & 55 & 37.76 & 19.86 & $\begin{array}{lll}156 & 48 & 049 \\
\end{array}$ & 10 & 5.2 & CMT \\
\hline 161 & $02 \quad 21$ & $04 \quad 59$ & 51 & 28.80 & 34.78 & $132 \quad 30 \quad-104$ & 10 & 5.1 & CMT \\
\hline 168 & $10 \quad 09$ & $13 \quad 10$ & 52 & 34.56 & 32.13 & $\begin{array}{lll}048 & 77 & 170 \\
\end{array}$ & 33 & 6.4 & CMT \\
\hline 169 & $\begin{array}{ll}10 & 09 \\
\end{array}$ & $14 \quad 00$ & 10 & 34.49 & 32.06 & $\begin{array}{lll}152 & 74 & 018 \\
\end{array}$ & 33 & 5.2 & A97 \\
\hline 170 & $10 \quad 09$ & $14 \quad 19$ & 37 & 34.59 & 32.20 & $\begin{array}{lll}046 & 79 & 159 \\
\end{array}$ & 33 & 5.7 & A97 \\
\hline 171 & $10 \quad 10$ & $01 \quad 10$ & 22 & 34.56 & 32.21 & $\begin{array}{lll}139 & 53 & 012\end{array}$ & 33 & 5.4 & CMT \\
\hline 172 & $10 \quad 10$ & $04 \quad 54$ & 46 & 34.85 & 32.29 & $\begin{array}{lll}147 & 62 & 004 \\
\end{array}$ & 33 & 4.9 & CMT \\
\hline 173 & $\begin{array}{lll}1996 & 11 & 27\end{array}$ & $00 \quad 44$ & 23 & 34.50 & 32.06 & $\begin{array}{llll}062 & 48 & -168\end{array}$ & 33 & 5.0 & CMT \\
\hline 175 & $\begin{array}{lll}1997 & 01 & 13 \\
\end{array}$ & 1019 & 26 & 34.31 & 32.33 & $\begin{array}{llll}097 & 76 & -011 \\
\end{array}$ & 33 & 5.3 & CMT \\
\hline 179 & $07 \quad 27$ & $10 \quad 07$ & 52 & 35.58 & 21.06 & $\begin{array}{lll}098 & 65 & 180 \\
\end{array}$ & 33 & 5.5 & CMT \\
\hline 180 & $10 \quad 13$ & $13 \quad 39$ & 37 & 36.38 & 22.07 & $\begin{array}{lll}298 & 20 & 089\end{array}$ & 24 & 6.2 & CMT \\
\hline 181 & 1105 & $12 \quad 22$ & 55 & 34.77 & 23.98 & $350 \quad 34 \quad 154$ & 33 & 5.1 & CMT \\
\hline 184 & $12 \quad 02$ & $19 \quad 22$ & 44 & 36.02 & 19.66 & $206 \quad 49 \quad-020$ & 33 & 4.7 & CMT \\
\hline 185 & $03 \quad 09$ & 1121 & 20 & 36.02 & 28.39 & $010 \quad 33-116$ & 72 & 5.1 & CMT \\
\hline
\end{tabular}


Table (1): Continue.

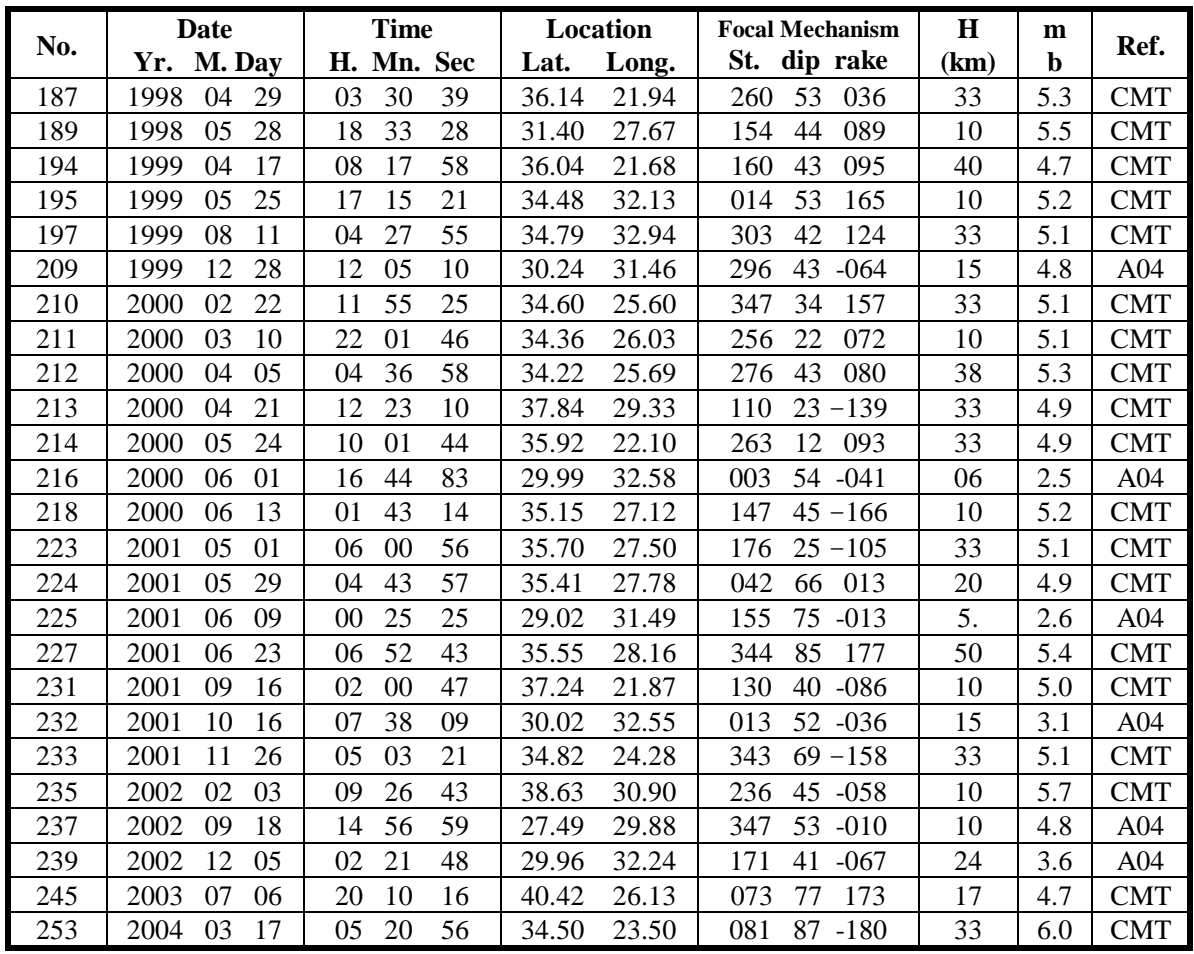

A97: Abou Elenean, 1997; S03, Salamon et al., 2003, K96 : Korrat et al., 1996 H90: Hassib, 1990, H87: Huang and Solomon, 1987, CMT: Harvard solutions.

\section{iv. Seismicity and Focal Mechanisms of the Northern Red Sea- Gulf of Suez}

The epicentral distribution map (Fig. 3) show that the seismic activity in the northern Red Sea is clustered at the entrance of the Gulf of Suez and the activity continues southward in the medial of the Red Sea. The cluster of the activity at this point may be due to the intersection of NW (Gulf of Suez -Red Sea) faults with the Aqaba trend. Few events are located in the central Red Sea almost at the transform faults crossing the rift axis.

Pedone et al. (1992) suggested that the seismic activity of the northern Red Sea can be related to the dislocations of transform (mainly NE-SW) and normal faults associated with the down dropping 
of blocks into the trough and to magmatic intrusions in the faulted Precambrian crust. The seismic activity extends to the north along the Suez rift and includes the northern part of the Eastern Desert. This trend is the major active trend inside the land of Egypt and extends towards Cairo and Alexandria toward northwest in the Mediterranean Sea.

The activity of this trend is attributed to the Red Sea rifting as well as to several active faults, which have trends NNW Parallel to the Red Sea-Gulf of Suez direction and its continuation toward East Mediterranean. Sofratome Group (1984) Supposed the possibility that Cairo- Alexandria fault zone (Fig. 4) absorbs the main effects of internal deformation in the northeast corner of Africa. This would rule out the occurrence of large earthquakes $(M>6)$ to the west of Alexandria. Also they suggested that this fault zone separate two different tectonic regimes especially in the Pliocene-Quaternary of the Eastern and Western Nile Delta. Field observation, landsat images and seismic profiles confirm this suggestion indicating active tectonics in the Eastern Desert between Suez and Cairo compared with the Western Desert of Egypt.

The focal mechanisms of few events along the northern Red Sea (Abu Eleneen, 1997) reflect normal faulting mechanism predominantly have nodal planes parallel to the rifting direction. Some of the focal mechanisms show a strike slip movement, which may be related to the events located at the transform faults that crossed the main rift direction, (Figs. 5 and 6). The stress tensor inversion for few earthquakes along the northern part of the Red Sea (Abou Elenean, 1997) show a stress axes $\sigma_{1}, \sigma_{2}$ and $\sigma_{3}$ directed azimuth/plunge 202/59, 318/15 and 56/27 which reflect a dominant tension stress (Fig. $9)$.

The focal mechanisms of few events have small to moderate size along the Gulf of Suez-Northern part of the Eastern Desert show normal faults with small component of strike slip movements. The strike slip component increased on land than a long the Gulf area. The 
fault planes are generally trending ENE-WSW to E-W and NNW-SSE to NW-SE (Abou Elenean, 1997). The Stress axes $\sigma_{1}, \sigma_{2}$ and $\sigma_{3}$ are trending azimuth/plunge 105/39, 341/34 and 226/32 respectively (Fig 10). This stress model reflects a dominant tension stress with considerable amount of strike slip components.

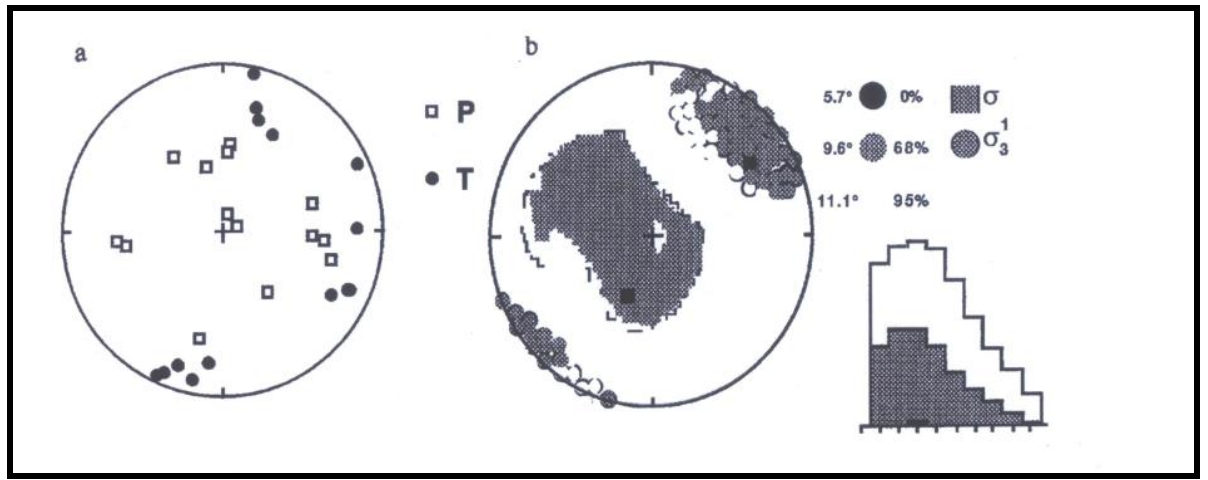

(a) The Distribution of the P- and T- axes; (b) best fit stress model, confidence ranges of the fit and histogram reflect the tested numbers of the stress models for different confidence limits.

Fig. (9): The best fit stress model for the northern Red Sea part.

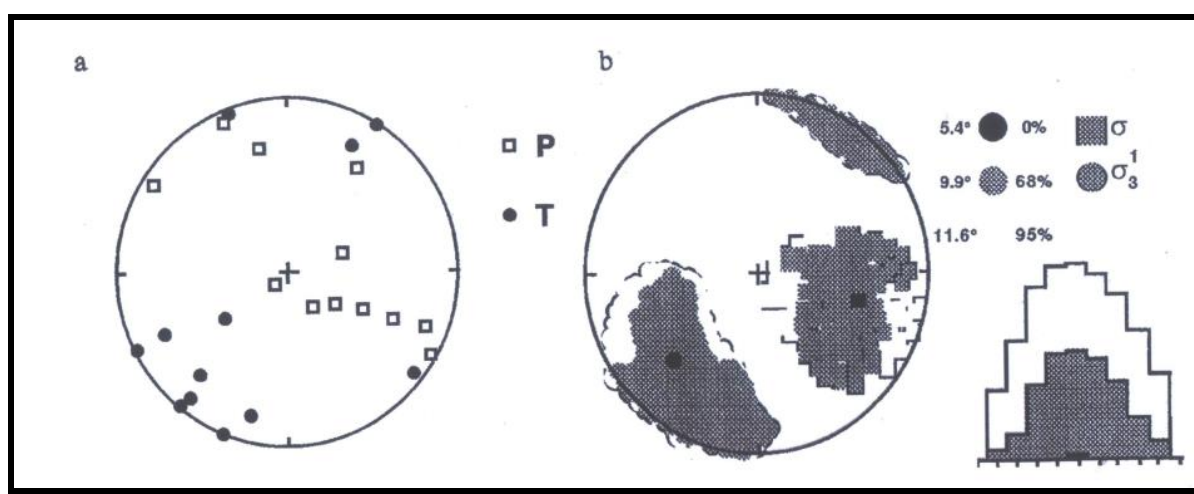

(a) Distribution of the P- and T- axes. (b) Best stress model with the other solutions for the different confidence limits and histogram reflect the numbers of the stress model inside different confidence ranges.

Fig. (10): Stress tensor inversion for the Gulf of Suez-northern eastern desert. 
Bosworth and Taviani (1996) concluded by analyzing borehole breakouts and mesoscopic fault arrays a dominant NNE-SSW extension stress. Northwest the Gulf of Suez, and outside the rift province the destructive 10/92 Cairo earthquake is most important. Its extensional mechanism combined with slight shear component, fits well with both the Suez rift system and the E-W transverse normal faults east of Cairo.

\section{v. Seismicity and Focal Mechanisms of the Aqaba-Levant Transform fault}

The seismic activity of this fault zone is relatively high (Fig. 3) and may be attributed to some local reasons as the upwelling magmas or the intersection of two or more tectonic elements (Fig. 4). The activity is trending NNE along the main fault of the Gulf and changed toward the north until Taurus. The activity is diffused in some places due to the intersection of transverse faults with the NNE main trend.

From previous focal mechanism solutions along this trend, the main trend of $\mathrm{T}$-axis is in $\mathrm{N} 51^{\circ} \mathrm{E}$ and for $\mathrm{P}$-axis is $\mathrm{N} 65^{\circ} \mathrm{W}$ (Abou Elenean, 1993). The focal mechanism solutions (Figs. 5 and 6) along this trend reflect strike slip faults predominantly with normal components. Few events on the eastern side of the Aqaba Gulf (northwestern part of Saudia Arabia) and to the north (southern Lebanon, northern Syria) show strike slip with reverse component. The solutions give nodal planes trending N-S to NNE-SSW (main fault trend) and NNW-SSE to ESE-WNW (transverse faults). These mechanisms can be interpreted as they are related to pull apart faulted basins directed mainly N-S and encountered by transverse faults along E-W or ESE-WNW.

The stress tensor inversion along the Aqaba Gulf gave stress axes $\sigma_{1}, \sigma_{2}$ and $\sigma_{3}$ trending azimuth/plunge 333/27, 114/56 and 233/18 (Fig. 11) which indicate a dominant strike slip movement with normal component (Abou Elenean, 1997). Various mechanisms appears at the juncture zone of Sinai, Arabia and Anatolia where the Dead Sea transform, the East Anatolian Fault and the Cyprina arc meet 
(Salamon et al., 2003). The overall deformation of the ArabianAnatolian boundary seems to separate into two components; a left lateral shear which is absorbed on ENE-striking faults and an NW thrusting on either steep or shallow dipping planes. Furthermore, an extension regime is found amid the shear and thrust, possibly related to the Iskendrun Bay. Salamon et al (2003) indicated that all earthquakes along the Dead Sea transform exhibit mainly sinistral transtension and transpression, reflecting its leaky manner and local change in the transform geometry. The presence of other unexpected mechanisms near the transform reflects the heterogeneous deformation it induces around.

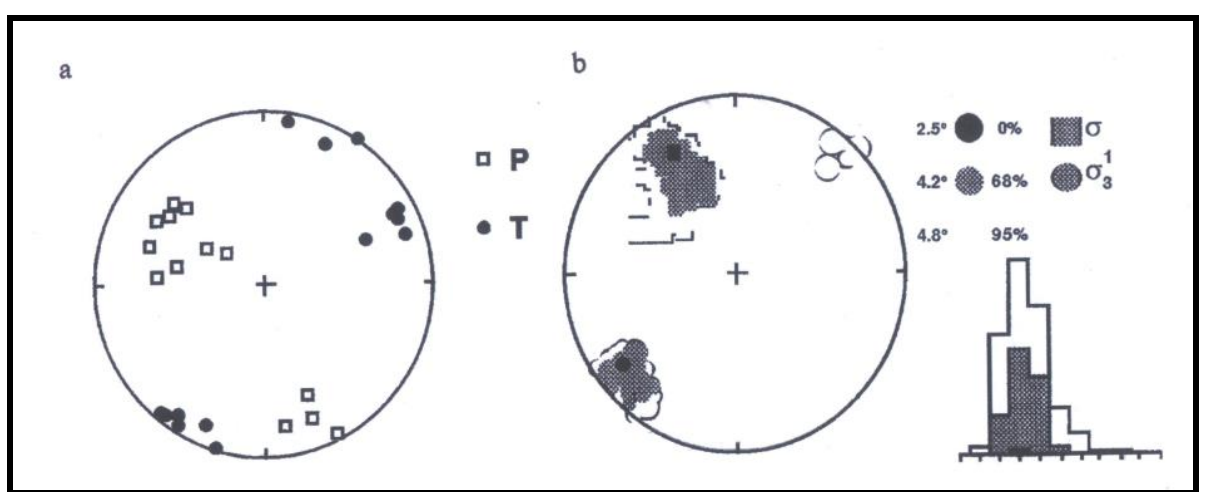

(a) Distribution of the P-an T- axes. b: best stress model with the other solution for different confidence limits and histogram reflects the numbers of the stress models within different confidence ranges.

Fig. (11): Stress trensor inversion for the Gulf of Aqaba zone.

\section{vi. Seismicity and Focal Mechanisms of Southern Red Sea and Yemen Territories:}

Previous works on the focal mechanism analysis in Yemen are very limited in number due to the small number of large events to be solved. Besides there did no seismic stations exist before 1994. There are many ways to determine the earthquake focal mechanism, one of them is done by using the polarity data of the recorded $\mathrm{P}$ and $\mathrm{S}$ waves and another one is done by the inversion of their recorded waveform. Figure (12) shows the seismic activity in Yemen. 


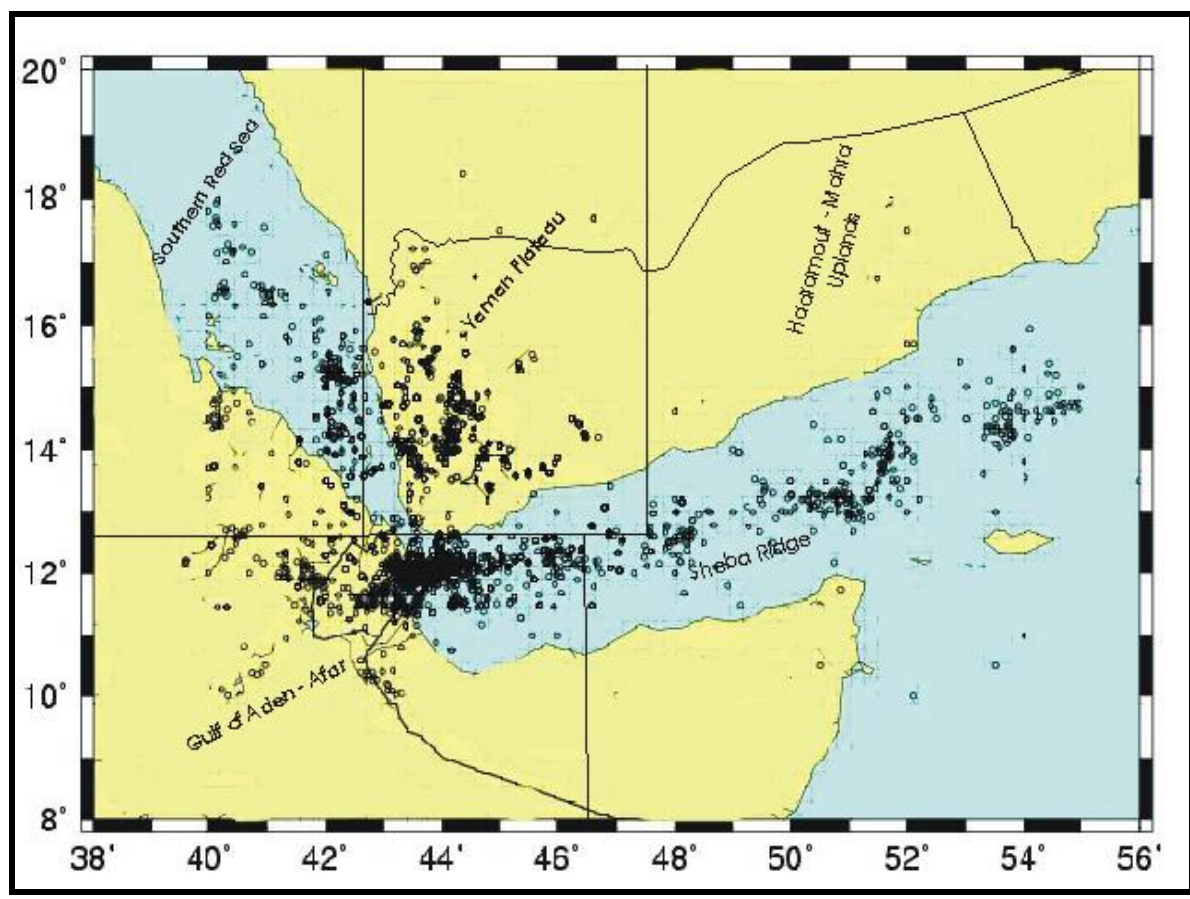

Fig. (12): Epicentral distribution of Yemen and surrounding areas for the period From 1975 to 2003.

The interpretation of the seismic activities were evaluated through the collected focal mechanisms that were done by previous works and that have been published by the world data centers (Harvard CMT) beside, the analysis and interpretation of our team. The studied area is divided into regional and local seismic zones (Fig. 13).

\section{C) Regional mechanism}

The current tectonic setting of Yemen is best understood by considering the overall geological history and evolution of the Arabian plate, Somalian plate and the southern Red Sea rift. The most active tectonic features are along plate boundaries, where the deformations are large. The plate motion also controls the deformations within individual plates. Hence the present day tectonic deformations within Yemen are related to the regional tectonic forces and to the local tectonics of Yemen. 
The stress field distribution represents a good key for understanding the tectonic situation and the direction of relative plate movements. The most common way for studying the seismotectonics of any specified region is done by plotting a stress field map on the basis of focal mechanisms, microtectonic analysis or in-situ stress measurements.

In this study about seventy eight (78) solutions by Harvard CMT have used to study the regional tectonic stresses. The parameters of these earthquakes are shown in tables (2) and (3). The focal mechanisms are projected using the lower hemisphere projection (Fig. 13).

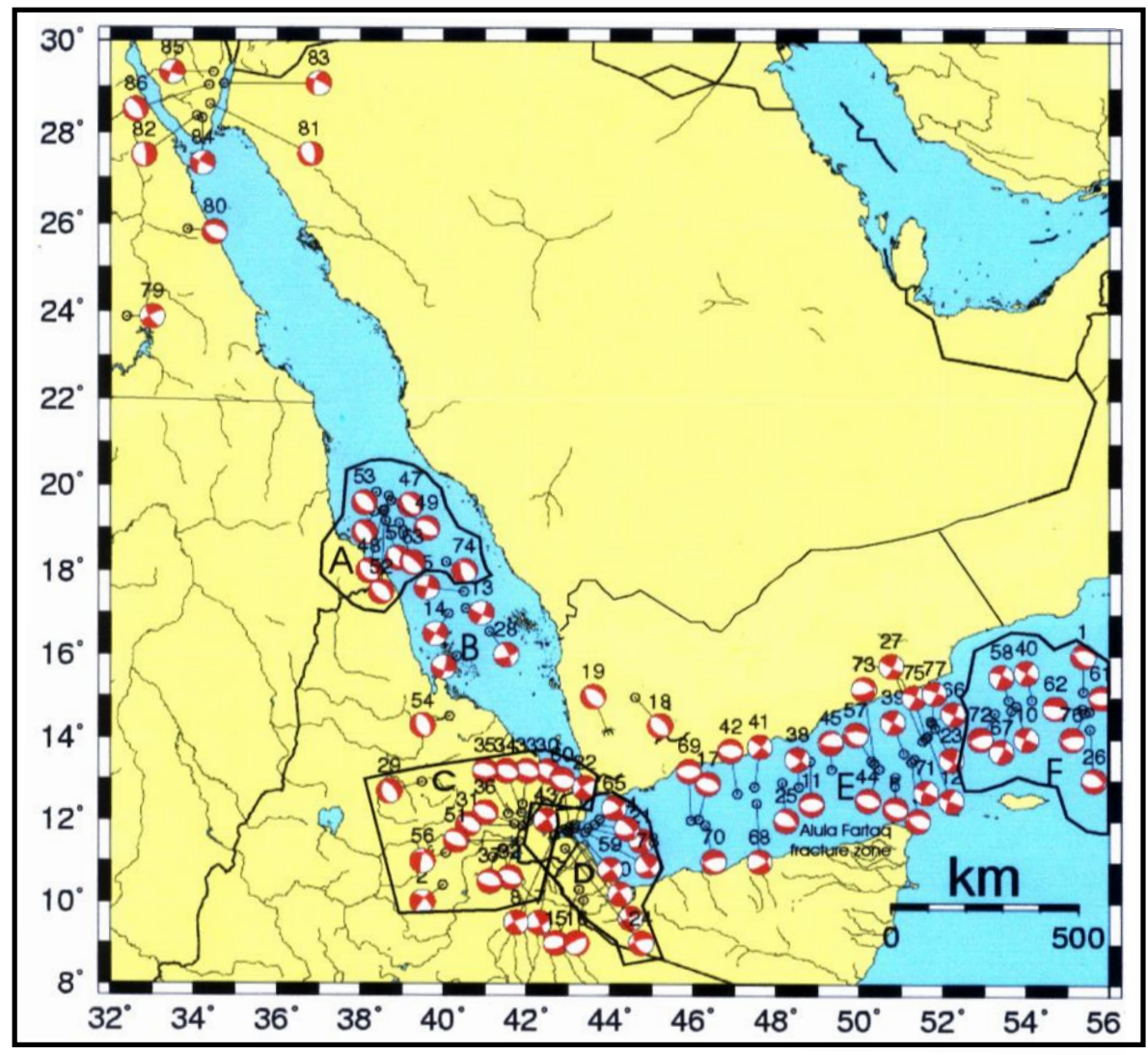

Fig. (13) : Focal Mechanism solutions and different seismic zones according to the (P-axis) and the Tension (T-axis) for the southern Red Sea and Yemeni Territories, (After A. Alaydros, 2003). 
Table (2): The Chosen Earthquakes of Magnitude Larger Than 5 According to Richter Scale and used for the Focal Mechanism Solutions.

\begin{tabular}{|c|c|c|c|c|c|}
\hline No. & Date & Lat. & Long. & Magnitude & Depth \\
\hline 1 & $1977 / 02 / 28$ & 15.16 & 55.37 & 5.3 & 10.0 \\
\hline 2 & $1977 / 07 / 08$ & 10.42 & 39.98 & 5.3 & 15.0 \\
\hline 3 & $1977 / 12 / 17$ & 13.45 & 51.25 & 5.4 & 15.0 \\
\hline 4 & $1977 / 12 / 28$ & 15.97 & 40.32 & 6.6 & 10.1 \\
\hline 5 & $1978 / 01 / 17$ & 17.51 & 40.49 & 5.4 & 15.0 \\
\hline 6 & $1978 / 02 / 11$ & 13.08 & 50.86 & 5.7 & 15.0 \\
\hline 7 & $1978 / 11 / 07$ & 11.64 & 42.67 & 5.9 & 15.0 \\
\hline 8 & $1978 / 11 / 08$ & 11.66 & 42.67 & 5.8 & 15.0 \\
\hline 9 & $1978 / 12 / 21$ & 11.79 & 42.91 & 5.7 & 15.0 \\
\hline 10 & $1979 / 07 / 08$ & 14.81 & 53.77 & 5.9 & 15.0 \\
\hline 11 & $1979 / 09 / 24$ & 13.46 & 48.81 & 5.2 & 15.0 \\
\hline 12 & $1979 / 12 / 22$ & 14.07 & 51.64 & 5.8 & 15.0 \\
\hline 13 & $1980 / 01 / 14$ & 17.12 & 40.53 & 6.0 & 15.0 \\
\hline 14 & $1980 / 01 / 14$ & 16.99 & 40.12 & 5.7 & 15.0 \\
\hline 15 & $1980 / 05 / 03$ & 10.31 & 43.26 & 5.6 & 15.0 \\
\hline 16 & $1980 / 05 / 30$ & 10.05 & 43.37 & 5.3 & 15.0 \\
\hline 17 & $1982 / 12 / 08$ & 12.03 & 46.13 & 5.6 & 14.2 \\
\hline 18 & $1982 / 12 / 13$ & 14.99 & 44.60 & 6.2 & 10.1 \\
\hline 19 & $1982 / 12 / 29$ & 14.10 & 43.97 & 5.5 & 15.0 \\
\hline 20 & $1983 / 09 / 28$ & 11.71 & 43.01 & 5.3 & 15.0 \\
\hline 21 & $1983 / 09 / 30$ & 11.83 & 43.47 & 5.7 & 37.4 \\
\hline 22 & $1983 / 10 / 19$ & 11.91 & 43.17 & 5.4 & 10.0 \\
\hline 23 & $1984 / 01 / 28$ & 14.27 & 51.82 & 5.7 & 10.0 \\
\hline 24 & $1985 / 06 / 04$ & 11.31 & 42.93 & 5.1 & 10.0 \\
\hline 25 & $1986 / 05 / 23$ & 12.94 & 48.14 & 5.7 & 15.0 \\
\hline 26 & $1987 / 06 / 16$ & 14.25 & 55.53 & 5.0 & 15.0 \\
\hline 27 & $1988 / 07 / 16$ & 13.96 & 51.52 & 5.6 & 15.0 \\
\hline 28 & $1988 / 12 / 10$ & 16.56 & 41.10 & 5.6 & 15.0 \\
\hline 29 & $1989 / 04 / 13$ & 12.94 & 39.48 & 5.4 & 15.0 \\
\hline 30 & $1989 / 08 / 20$ & 11.99 & 42.04 & 6.5 & 15.9 \\
\hline 31 & $1989 / 08 / 20$ & 11.86 & 41.90 & 6.1 & 15.0 \\
\hline 32 & $1989 / 08 / 20$ & 11.32 & 41.42 & 5.7 & 15.0 \\
\hline 33 & $1989 / 08 / 20$ & 12.40 & 41.91 & 6.1 & 15.0 \\
\hline 34 & $1989 / 08 / 21$ & 12.19 & 41.88 & 6.4 & 15.0 \\
\hline 35 & $1989 / 08 / 21$ & 12.17 & 41.56 & 6.1 & 15.0 \\
\hline 36 & $1989 / 08 / 21$ & 11.92 & 41.71 & 5.8 & 15.0 \\
\hline 37 & $1989 / 08 / 21$ & 11.10 & 41.18 & 5.3 & 15.0 \\
\hline 38 & $1989 / 11 / 24$ & 12.83 & 48.55 & 5.5 & 15.0 \\
\hline
\end{tabular}

$-32-$ 
Table (2): Continue.

\begin{tabular}{|c|c|c|c|c|c|}
\hline No. & Date & Lat. & Long. & Magnitude & Depth \\
\hline 39 & $1990 / 09 / 14$ & 13.66 & 51.06 & 5.5 & 15.0 \\
\hline 40 & $1990 / 11 / 03$ & 14.95 & 54.13 & 5.2 & 15.0 \\
\hline 41 & 1991/05/11 & 12.84 & 47.48 & 5.4 & 15.0 \\
\hline 42 & $1991 / 05 / 12$ & 12.67 & 47.07 & 5.5 & 15.0 \\
\hline 43 & $1992 / 03 / 05$ & 11.75 & 42.98 & 6.2 & 15.5 \\
\hline 44 & $1992 / 05 / 21$ & 13.28 & 50.48 & 5.2 & 15.0 \\
\hline 45 & $1993 / 01 / 08$ & 13.26 & 49.33 & 5.5 & 15.0 \\
\hline 46 & $1993 / 03 / 12$ & 19.39 & 38.34 & 5.3 & 15.0 \\
\hline 47 & $1993 / 03 / 12$ & 19.76 & 38.68 & 5.0 & 15.0 \\
\hline 48 & $1993 / 03 / 13$ & 19.42 & 38.55 & 5.7 & 15.0 \\
\hline 49 & $1993 / 03 / 14$ & 19.65 & 38.74 & 4.9 & 15.0 \\
\hline 50 & $1993 / 03 / 16$ & 19.18 & 38.61 & 5.3 & 15.0 \\
\hline 51 & $1993 / 03 / 16$ & 11.49 & 41.82 & 5.6 & 15.0 \\
\hline 52 & $1993 / 03 / 22$ & 19.43 & 38.59 & 5.0 & 15.0 \\
\hline 53 & $1993 / 03 / 23$ & 19.85 & 38.39 & 5.2 & 16.3 \\
\hline 54 & $1993 / 05 / 06$ & 14.52 & 40.14 & 5.2 & 15.0 \\
\hline 55 & 1993/08/01 & 15.37 & 31.35 & 5.5 & 15.0 \\
\hline 56 & $1993 / 09 / 21$ & 11.19 & 40.05 & 5.7 & 15.0 \\
\hline 57 & $1993 / 10 / 12$ & 13.48 & 50.29 & 5.2 & 15.0 \\
\hline 58 & 1993/11/09 & 14.94 & 53.58 & 5.6 & 15.0 \\
\hline 59 & 1994/04/11 & 11.82 & 43.15 & 5.9 & 15.0 \\
\hline 60 & $1994 / 04 / 24$ & 11.85 & 43.03 & 5.6 & 15.0 \\
\hline 61 & $1995 / 12 / 07$ & 14.68 & 55.52 & 5.3 & 15.0 \\
\hline 62 & $1996 / 03 / 14$ & 14.75 & 55.35 & 5.2 & 15.0 \\
\hline 63 & 1996/11/02 & 19.13 & 38.94 & 5.3 & 15.0 \\
\hline 64 & $1997 / 03 / 08$ & 11.90 & 43.64 & 5.3 & 15.0 \\
\hline 65 & 1997/03/09 & 12.04 & 43.75 & 5.5 & 15.0 \\
\hline 66 & $1997 / 06 / 07$ & 14.43 & 51.72 & 5.4 & 15.0 \\
\hline 67 & 1998/10/01 & 14.69 & 53.65 & 5.6 & 15.0 \\
\hline 68 & $1998 / 11 / 23$ & 12.43 & 47.54 & 5.4 & 15.0 \\
\hline 69 & $2000 / 02 / 10$ & 12.01 & 45.95 & 5.1 & 15.0 \\
\hline 70 & $2000 / 02 / 14$ & 11.89 & 46.30 & 5.4 & 15.0 \\
\hline 71 & $2000 / 06 / 24$ & 13.52 & 51.32 & 5.3 & 15.0 \\
\hline 72 & $2001 / 03 / 25$ & 14.63 & 53.25 & 5.1 & 15.0 \\
\hline 73 & $2001 / 04 / 23$ & 13.41 & 50.35 & 5.3 & 15.0 \\
\hline 74 & $2001 / 05 / 25$ & 18.21 & 40.07 & 5.2 & 15.0 \\
\hline 75 & $2001 / 06 / 15$ & 14.03 & 51.59 & 5.9 & 15.0 \\
\hline 76 & $2001 / 07 / 14$ & 14.64 & 55.41 & 5.2 & 15.0 \\
\hline 77 & $2001 / 08 / 26$ & 14.38 & 51.74 & 5.6 & 15.0 \\
\hline 78 & $2001 / 11 / 02$ & 11.72 & 43.41 & 5.1 & 15.0 \\
\hline
\end{tabular}

-33- 
Table (3): The Extracted Parameters from the Focal Mechanism Solutions for the Chosen Earthquakes.

\begin{tabular}{|c|c|c|c|c|c|c|c|c|c|c|}
\hline & \multicolumn{3}{|c|}{ Plane I } & \multicolumn{3}{|c|}{ Plane II } & \multicolumn{2}{|c|}{ P-axis } & \multicolumn{2}{|c|}{$\mathrm{T}$-axis } \\
\hline & Strike & Dip & Rake & Strike & Dip & Rake & Azimuth & Plunge & Azimuth & Plunge \\
\hline 1 & 274 & 048 & -118 & 132 & 049 & -063 & 112 & 70 & 203 & 01 \\
\hline 2 & 310 & 066 & -171 & 216 & 082 & -024 & 171 & 23 & 265 & 11 \\
\hline 3 & 270 & 045 & -117 & 126 & 051 & -066 & 100 & 71 & 199 & 03 \\
\hline 4 & 106 & 066 & -171 & 013 & 081 & -024 & 327 & 23 & 061 & 11 \\
\hline 5 & 282 & 090 & 180 & 012 & 090 & 000 & 147 & 00 & 057 & 00 \\
\hline 6 & 116 & 039 & -079 & 282 & 052 & -990 & 151 & 81 & 018 & 06 \\
\hline 7 & 064 & 065 & -178 & 334 & 089 & -025 & 286 & 19 & 221 & 19 \\
\hline 8 & 150 & 080 & -009 & 242 & 081 & -170 & 106 & 13 & 016 & 01 \\
\hline 9 & 155 & 076 & -012 & 247 & 078 & -166 & 112 & 18 & 021 & 02 \\
\hline 10 & 203 & 080 & 178 & 293 & 088 & 010 & 068 & 06 & 159 & 08 \\
\hline 11 & 268 & 045 & -090 & 088 & 045 & -090 & 088 & 90 & 178 & 00 \\
\hline 12 & 204 & 073 & -176 & 113 & 086 & -017 & 067 & 15 & 160 & 09 \\
\hline 13 & 024 & 076 & -009 & 116 & 081 & -166 & 341 & 16 & 250 & 04 \\
\hline 14 & 301 & 090 & 180 & 031 & 090 & 000 & 166 & 00 & 076 & 00 \\
\hline 15 & 280 & 040 & -068 & 072 & 054 & -107 & 090 & 74 & 175 & 07 \\
\hline 16 & 022 & 023 & -130 & 244 & 073 & -075 & 176 & 60 & 322 & 26 \\
\hline 17 & 105 & 039 & -093 & 288 & 051 & -088 & 215 & 84 & 017 & 06 \\
\hline 18 & 134 & 037 & -095 & 320 & 053 & -086 & 248 & 81 & 048 & 08 \\
\hline 19 & 303 & 043 & -107 & 145 & 049 & -075 & 120 & 78 & 225 & 03 \\
\hline 20 & 232 & 067 & 174 & 324 & 084 & 023 & 096 & 12 & 191 & 20 \\
\hline 21 & 058 & 067 & -168 & 324 & 079 & -023 & 279 & 24 & 012 & 08 \\
\hline 22 & 232 & 074 & -165 & 137 & 076 & -017 & 095 & 22 & 185 & 01 \\
\hline 23 & 025 & 069 & 170 & 118 & 081 & 021 & 249 & 08 & 342 & 22 \\
\hline 24 & 149 & 054 & -027 & 256 & 069 & -140 & 118 & 42 & 019 & 09 \\
\hline 25 & 314 & 044 & -062 & 098 & 052 & -114 & 307 & 70 & 204 & 04 \\
\hline 26 & 310 & 049 & -056 & 084 & 051 & -123 & 289 & 65 & 197 & 01 \\
\hline 27 & 028 & 076 & 175 & 119 & 085 & 014 & 253 & 06 & 343 & 13 \\
\hline 28 & 339 & 074 & -017 & 074 & 074 & -163 & 296 & 23 & 026 & 00 \\
\hline 29 & 168 & 039 & -070 & 323 & 054 & -106 & 184 & 75 & 064 & 08 \\
\hline 30 & 301 & 045 & -090 & 121 & 045 & -090 & 121 & 90 & 211 & 00 \\
\hline 31 & 288 & 038 & -109 & 130 & 055 & -076 & 086 & 76 & 211 & 08 \\
\hline 32 & 294 & 045 & -090 & 114 & 045 & -090 & 113 & 90 & 204 & 00 \\
\hline 33 & 285 & 034 & -092 & 108 & 056 & -089 & 022 & 79 & 196 & 11 \\
\hline 34 & 281 & 045 & -101 & 116 & 046 & -079 & 105 & 82 & 199 & 01 \\
\hline 35 & 290 & 041 & -077 & 092 & 051 & -101 & 309 & 80 & 191 & 05 \\
\hline 36 & 296 & 045 & -090 & 116 & 045 & -090 & 116 & 90 & 206 & 00 \\
\hline 37 & 296 & 032 & -078 & 102 & 059 & -097 & 351 & 75 & 197 & 13 \\
\hline 38 & 041 & 067 & -168 & 307 & 079 & -024 & 262 & 24 & 355 & 08 \\
\hline
\end{tabular}

$-34-$ 
Table (3): Continue.

\begin{tabular}{|c|c|c|c|c|c|c|c|c|c|c|}
\hline & \multicolumn{3}{|c|}{ Plane I } & \multicolumn{3}{|c|}{ Plane II } & \multicolumn{2}{|c|}{ P-axis } & \multicolumn{2}{|c|}{ T-axis } \\
\hline & Strike & Dip & Rake & Strike & Dip & Rake & Azimuth & Plunge & Azimuth & Plunge \\
\hline 39 & 207 & 090 & -180 & 297 & 090 & 000 & 108 & 00 & 197 & 00 \\
\hline 40 & 212 & 090 & -180 & 302 & 090 & 000 & 103 & 00 & 167 & 00 \\
\hline 41 & 308 & 082 & -008 & 040 & 082 & -172 & 264 & 11 & 174 & 00 \\
\hline 42 & 275 & 045 & -090 & 095 & 045 & -090 & 095 & 90 & 185 & 00 \\
\hline 43 & 324 & 074 & 003 & 233 & 087 & 164 & 280 & 09 & 187 & 13 \\
\hline 44 & 284 & 045 & -090 & 104 & 045 & -090 & 104 & 90 & 194 & 00 \\
\hline 45 & 231 & 030 & -134 & 099 & 069 & -068 & 041 & 60 & 173 & 21 \\
\hline 46 & 148 & 031 & -083 & 320 & 059 & -094 & 218 & 75 & 014 & 53 \\
\hline 47 & 321 & 045 & -090 & 141 & 045 & -090 & 141 & 90 & 231 & 00 \\
\hline 48 & 144 & 040 & -084 & 316 & 050 & -095 & 193 & 84 & 050 & 05 \\
\hline 49 & 301 & 045 & -090 & 121 & 045 & -090 & 121 & 90 & 211 & 00 \\
\hline 50 & 127 & 038 & -114 & 335 & 056 & -073 & 293 & 73 & 054 & 09 \\
\hline 51 & 308 & 037 & -076 & 110 & 055 & -100 & 344 & 78 & 208 & 09 \\
\hline 52 & 315 & 045 & -090 & 135 & 045 & -090 & 135 & 90 & 225 & 00 \\
\hline 53 & 313 & 045 & -090 & 133 & 045 & -090 & 133 & 90 & 223 & 00 \\
\hline 54 & 337 & 045 & -090 & 157 & 045 & -090 & 157 & 90 & 247 & 00 \\
\hline 55 & 172 & 063 & -014 & 269 & 077 & -152 & 133 & 28 & 038 & 10 \\
\hline 56 & 299 & 038 & -159 & 192 & 077 & -054 & 139 & 45 & 255 & 24 \\
\hline 57 & 137 & 037 & -048 & 269 & 063 & -117 & 136 & 62 & 018 & 14 \\
\hline 58 & 294 & 075 & 003 & 203 & 087 & 165 & 250 & 08 & 158 & 13 \\
\hline 59 & 318 & 078 & -002 & 049 & 088 & -168 & 274 & 10 & 183 & 07 \\
\hline 60 & 120 & 034 & -067 & 273 & 059 & -105 & 148 & 72 & 014 & 13 \\
\hline 61 & 272 & 045 & -090 & 092 & 045 & -090 & 092 & 90 & 182 & 00 \\
\hline 62 & 072 & 020 & -118 & 282 & 072 & -080 & 206 & 61 & 004 & 27 \\
\hline 63 & 153 & 020 & -068 & 310 & 072 & -098 & 208 & 63 & 046 & 26 \\
\hline 64 & 077 & 047 & -143 & 320 & 064 & -050 & 279 & 53 & 022 & 10 \\
\hline 65 & 315 & 058 & -024 & 058 & 070 & -146 & 280 & 38 & 184 & 08 \\
\hline 66 & 024 & 081 & 177 & 114 & 087 & 009 & 249 & 04 & 340 & 08 \\
\hline 67 & 290 & 058 & -009 & 025 & 082 & -148 & 252 & 28 & 153 & 16 \\
\hline 68 & 305 & 053 & -033 & 056 & 064 & -138 & 276 & 47 & 178 & 07 \\
\hline 69 & 270 & 045 & -090 & 090 & 045 & -090 & 090 & 90 & 180 & 00 \\
\hline 70 & 120 & 031 & -052 & 257 & 066 & -111 & 135 & 63 & 003 & 19 \\
\hline 71 & 205 & 070 & 177 & 296 & 087 & 020 & 069 & 12 & 162 & 16 \\
\hline 72 & 109 & 029 & -056 & 251 & 066 & -107 & 132 & 65 & 354 & 20 \\
\hline 73 & 304 & 040 & -045 & 072 & 063 & -120 & 296 & 60 & 183 & 13 \\
\hline 74 & 303 & 036 & -128 & 167 & 063 & -066 & 118 & 64 & 240 & 14 \\
\hline 75 & 293 & 077 & -007 & 025 & 083 & -167 & 249 & 14 & 158 & 04 \\
\hline 76 & 121 & 027 & -053 & 261 & 069 & -107 & 144 & 62 & 004 & 22 \\
\hline 77 & 292 & 078 & -013 & 025 & 078 & -167 & 248 & 18 & 338 & 00 \\
\hline 78 & 053 & 063 & 179 & 143 & 089 & 027 & 275 & 18 & 012 & 19 \\
\hline
\end{tabular}

-35 - 


\section{i. Southern Red Sea}

The focal mechanism solutions of the events located in the southern Red Sea (group A) suggest pure normal faulting mechanism (Fig. 13), with a NNE-SSW trending tension axis (Fig. 14). These events took place along the rift valley region which is characterized by continuous sea floor spreading.

To the south of group A events, there is another group events (Fig. 13, group B) reflecting strike slip mechanisms. Events no. 13, 14 and 22 took place along one of the NNE-SSW transform faults. The plane trending NNE-SSW indicating left lateral motion along this transform fault. Event 28 took place along NNW-SSE trending fault to the west of the rift valley. The mechanism of this event reflects strike slip mechanism with a left lateral motion along a NNW-SSS trending plane. Some events took place to the east of the rift valley along a NNW-SSE trending fault. The focal mechanism of this event shows strike slip mechanism along the same trend with a right lateral motion.

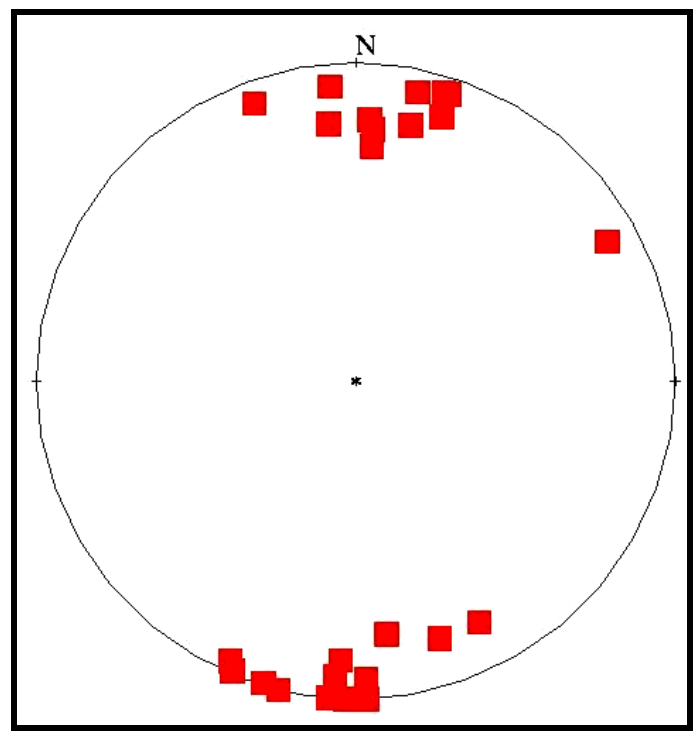

Fig. (14): Shows the NNE-SSW Trending Tension Axis in the Southern Red Sea. 


\section{ii. East African Rift (EAR)}

The focal mechanism of events along the EAR spreading (group C) system indicates typical normal faulting mechanism for most parts (Fig. 13) with an average tension axis oriented NE-SW (Fig. 15) reflecting a continental divergent plate boundary.

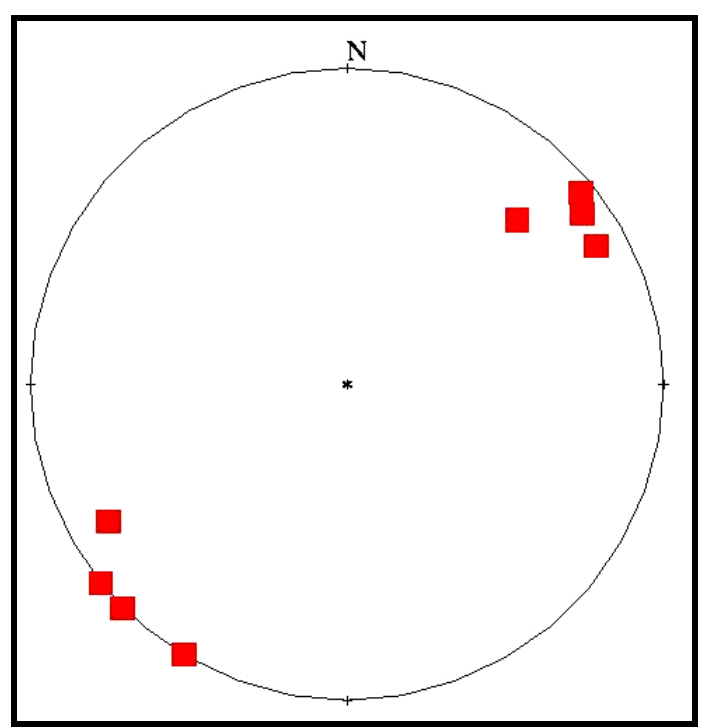

Fig. (15): Shows the Average Tension Axis oriented NE-SW in the East African Rift Reflecting a Continental Divergent Plate Boundary.

\section{iii. Gulf of Aden}

Generally the focal mechanism solutions in the Gulf of Aden (Fig.13) region shows two types of faulting normal and strike slip. Normal faulting mechanisms are associated with the spreading while the strike slip ones are related to the existing transform faults. The average direction of the tension axis in the Gulf of Aden is NNE-SSW (Fig. 16).

For the events that took place at the extreme west of the Gulf of Aden (Tadjura Gulf), (Fig. 13, group D). The majority of the epicenters are associated with the transform faults suggesting strike slip mechanism with a dip slip component. 
The presence of such a mechanism reflects a westward extension of the transform fault system and extensional mechanism existing in the Gulf of Aden.

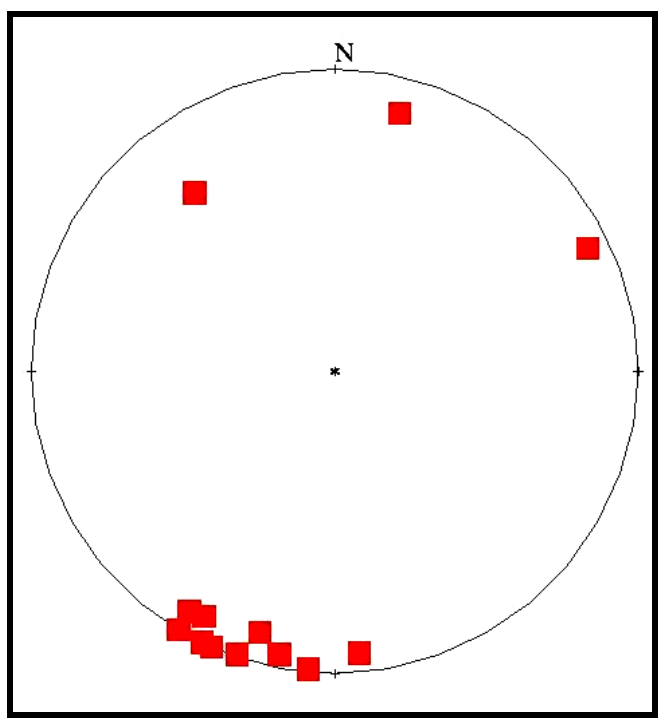

Fig. (16): Shows the Average Direction of the Tension Axis in the Gulf of Aden as NNE-SSW.

\section{iv. Sheba -Ridge}

The seismic activity along this zone is aligned conformably along the main rift axis nearly NWW-SEE. The activity also shows that the rift axis have been transformed by some NE-SW right central strike slip faults. The focal mechanisms (Fig. 13) indicate two types of fault mechanisms, the first shows a normal faulting mechanism while the second is strike slip faults. The normal faulting is trending nearly E-W along Sheba Ridge, (events no. 1, 61, 76, 26, 62), (group F). The events no. 40, 58, 10, and 67 indicate NE-SW transform faults that bisect the Sheba Ridge. The focal mechanism of events no. 12, 23, 66, $77,75,27$ and 71 identify strike slip faults That is obvious from the group located to the right from group E. These events are in coincidence with the Alula-Fartak transform fault which has been reflected by previous magnetic and gravity studies. 


\section{v. Gulf of Aden-Afar rift mechanism}

The fault plane solution of events no. 6, 44 and 57 reflect normal faults trending NW-SE in agreement with the Aswad ridge direction, figure (13). The extension that caused this ridge has extended toward north inland inside Yemen as reflected by the existence of AtaqBalhaf Trough and Hajr Trough, the mechanisms numbers 67, 69 and 70 indicate normal faulting parallel to the main rift towards Afar. Along the Afar area the solution of about seven events show a normal faulting mechanism that tends to change its direction from E-W to NW-SE close to the Red Sea.

\section{vi. Southern Red Sea}

The focal mechanisms of the events lying along the southern part of the Red Sea show two types of faults, figure (13). The first one from the south indicates normal faulting with large strike-slip components. These solutions have two planes trending NE-SE and NE-SW as clearly shown for events no. 4, 3, 13 and 14. The second solution along the southern Red Sea reflects pure normal faulting trending parallel to the Red Sea direction (NW-SE), (see solution of Events No. 48, 49, 50, 52, 63 and 74).

\section{D) Stress field}

The stress fields based on the previous focal mechanism of the different seismic zones according to our study have been selected and the average direction of pressure axis (P-axis) and tension axis ( $\mathrm{T}$ axis) are calculated for each zone. The source parameters of these focal mechanisms are listed in table (3).

The distribution of the $\mathrm{P}$ and $\mathrm{T}$ axis for the Gulf of Aden- Afar rift shows a dominant $\mathrm{T}$-axis directed $\mathrm{N} 25^{\circ} \mathrm{E}$. Also, the $\mathrm{T}$-axis is more horizontal and dominant along the Southern Red Sea part and trending $\mathrm{N} 45^{\circ} \mathrm{E}$.

Volcanic activity and high geothermal activity characterize the Yemen region. Also the surface faults and dykes suggest extension stresses act in the region. Orientation of these faults and dykes is not uniform, which indicates a complex tectonic process in the region. All 
these tectonic features suggest extension tectonics caused by upwelling of hot mantel material beneath the Yemen region. Figure (17) shows the evaluated compiled solution for general stress field trend for the study region deduced from the analysis of focal mechanism solutions.

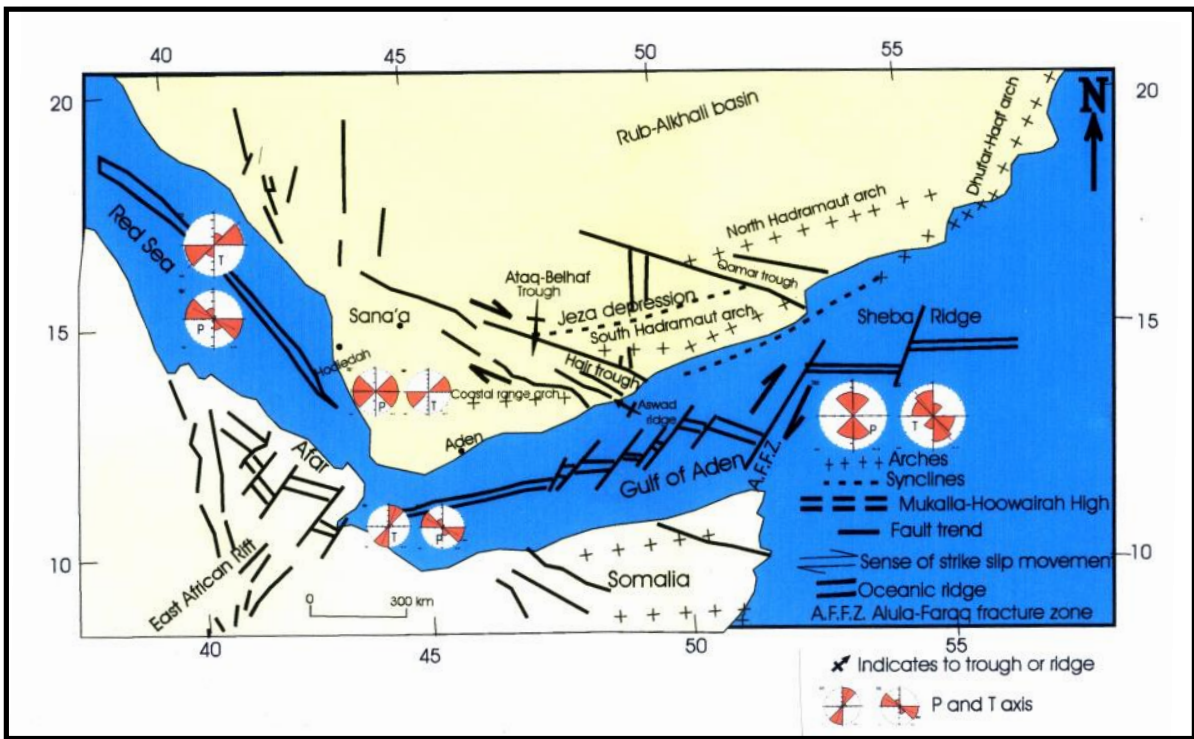

Fig. (17): Evaluated compiled solutions for the general stress field of the southern Red Sea and Yemeni borders deduce from focal mechanism analysis.

\section{E) GPS data Analysis}

As we have mentioned before in section (2.1), we used Bernese Ver. 4.2 software (2001) following all constraints and best fetting and consedring the International Rreference Frame and including the important IGS stations for controlling the work, figures (18-20) show the time series for some of these anchor sites. Considering the previous studies, McCluski et al. (2003) deduced the relative motion of Africa plate versus Eurasia plate to be as westward motion and slower convergence in the Mediterranean. That study had been done by collaborative work between MIT and "NRIAG, Helwan", figure (21). We have used here Matrouh station (MATR) in the western north of Egypt to be within the chosen points of the GPS geodetic network 
(Yemen-Egypt) and we added another point in the western desert at Kharga (KHRG), review figure (1). Our output results for Matrouh is convenient with that resulted by McCluksy et al, 2003 which asserts the reality of the steady rate motion of the African plate even extracted from the seismological or the GPS data analysis. We have concentrated on the seismological data in the northern Mediterranean Sea to compensate the lack of GPS stations.

The analysis of these focal mechanism solutions are compared with the general trends of the movements deduced from the geodetic analysis and are compliant to a great extent with that deduced from the geodetic data analysis asserting the general trends of the resulted extensional and compressional forces and also the general trend of the fault system. Figure (22) shows the displacement vector deduced from the geodetic GPS data analysis. These are the relative displacements as the final solution in the ITRF 2000 reference frame using Bernese 4.2. Table (4) presents the results of the whole used stations and its coordinates.

Table (4): The whole used stations and its precise coordinates resulted from Bernese V.4.2 Software.

\begin{tabular}{|l|c|c|c|}
\hline \multicolumn{1}{|c|}{ Station Name } & X $(\mathbf{M})$ & Y $(\mathbf{M})$ & $\mathbf{Z}(\mathbf{M})$ \\
\hline ADEN (Asia) & 4395393.0338 & 4401520.1786 & 1405159.6320 \\
\hline AMMN 22201M001 (Asia) & 4386124.5329 & 3172638.1206 & 3363685.1977 \\
\hline BAHR 24901M002 (Asia) & 3633908.9516 & 4425275.4972 & 2799861.3548 \\
\hline DAHA (Asia) & 4623441.3966 & 3174030.6311 & 3028186.0732 \\
\hline HODE (Asia) & 4514928.9872 & 4203438.0778 & 1615446.4213 \\
\hline HURG (Africa) & 4713701.0127 & 3159396.8280 & 2902338.3516 \\
\hline IISC 22306M001 (Asia) & 1337937.1312 & 6070315.4090 & 1427876.3726 \\
\hline KRGA (Africa) & 4918638.5311 & 2923071.5524 & 2809674.4495 \\
\hline MALI 33201M001B (Africa) & 4865366.4203 & 4110737.4754 & -331121.6483 \\
\hline MATE 12734M008 (Europe) & 4641949.6062 & 1393045.3734 & 4133287.4132 \\
\hline MKLA (Asia) & 4049124.6761 & 4664309.0865 & 1585127.2400 \\
\hline MTRH (Africa) & 4847936.8523 & 2494798.5872 & 3298699.8297 \\
\hline NKLG 32809M002 (Africa) & 6287385.8013 & 1071574.4590 & 39132.839900 \\
\hline RAMO 20703S001 (Asia) & 4514721.9460 & 3133507.7718 & 3228024.5941 \\
\hline SANA (Asia) & 412796.86010 & 4289811.5371 & 1677895.8452 \\
\hline SYON (Asia) & 4043087.1904 & 4614079.5147 & 1741301.7812 \\
\hline UNIV (Asia) & 4896745.2284 & 3164031.4253 & 2578555.1427 \\
\hline WTZR 14201M010 (Europe) & 4075580.6330 & 931853.71700 & 4801568.0828 \\
\hline
\end{tabular}




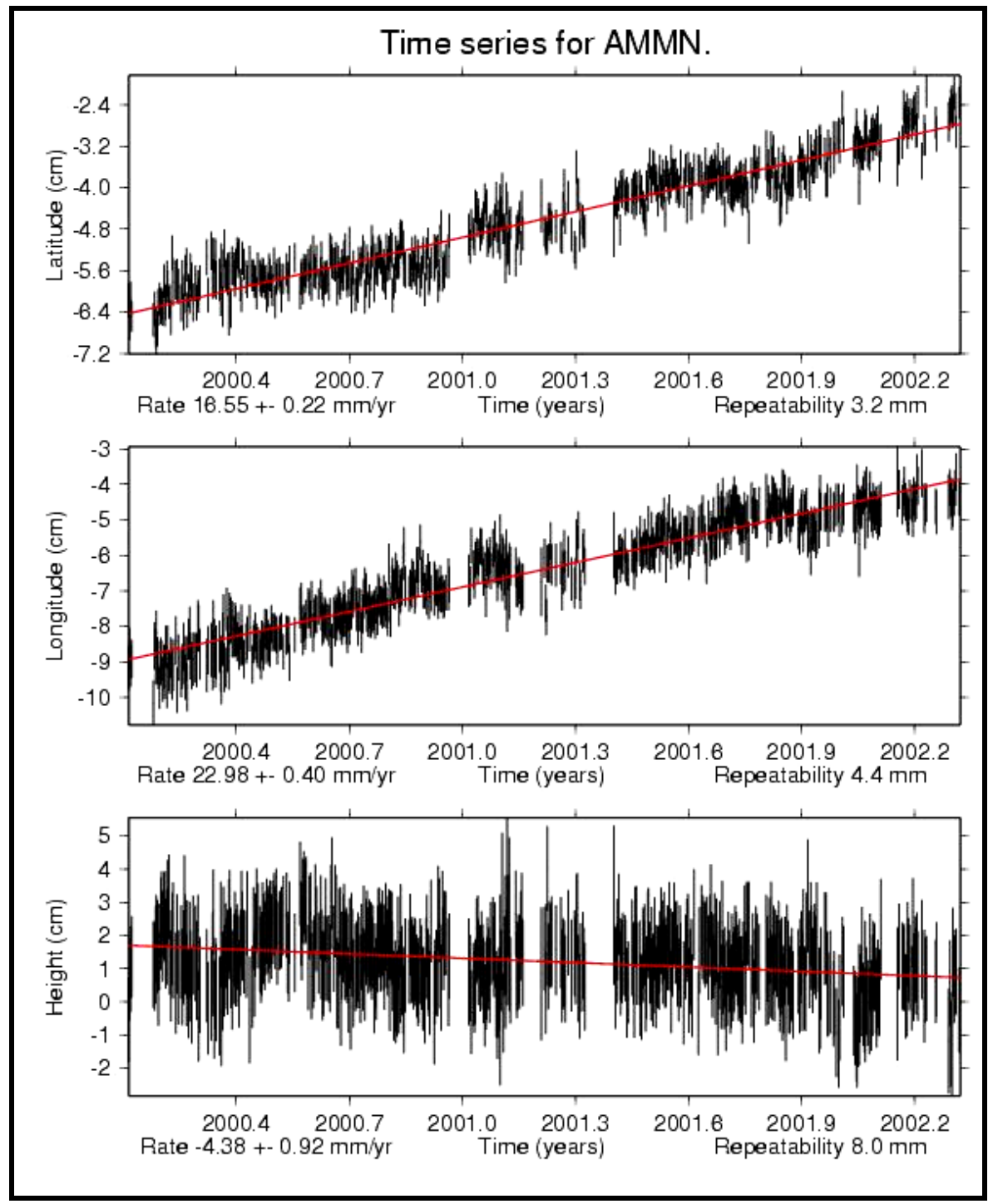

Fig. (18): Time Series for IGS Station Amman, Jordan (AMMN). 


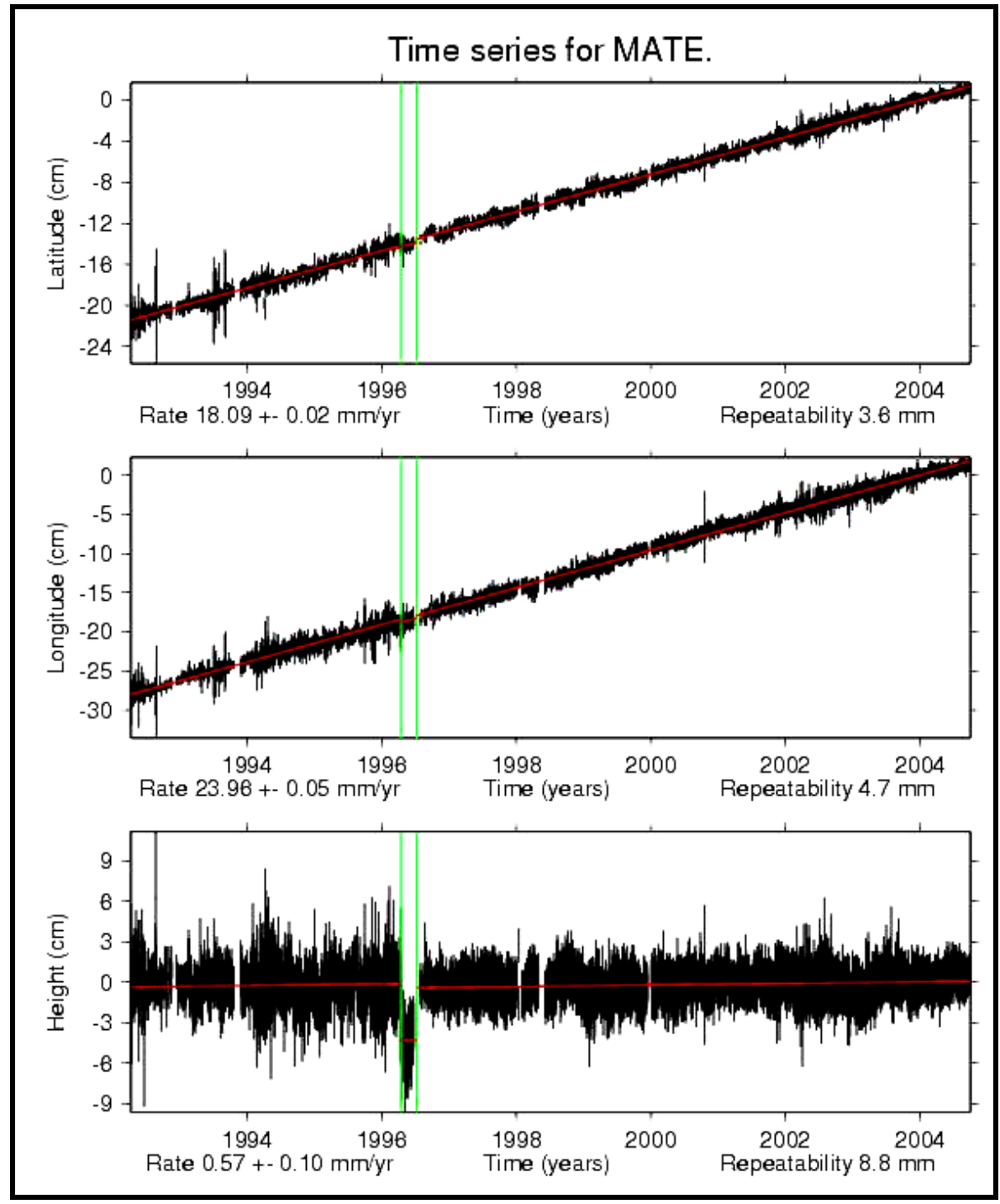

Fig. (19): Time Series for IGS Station Matera, Italy (MATE) 


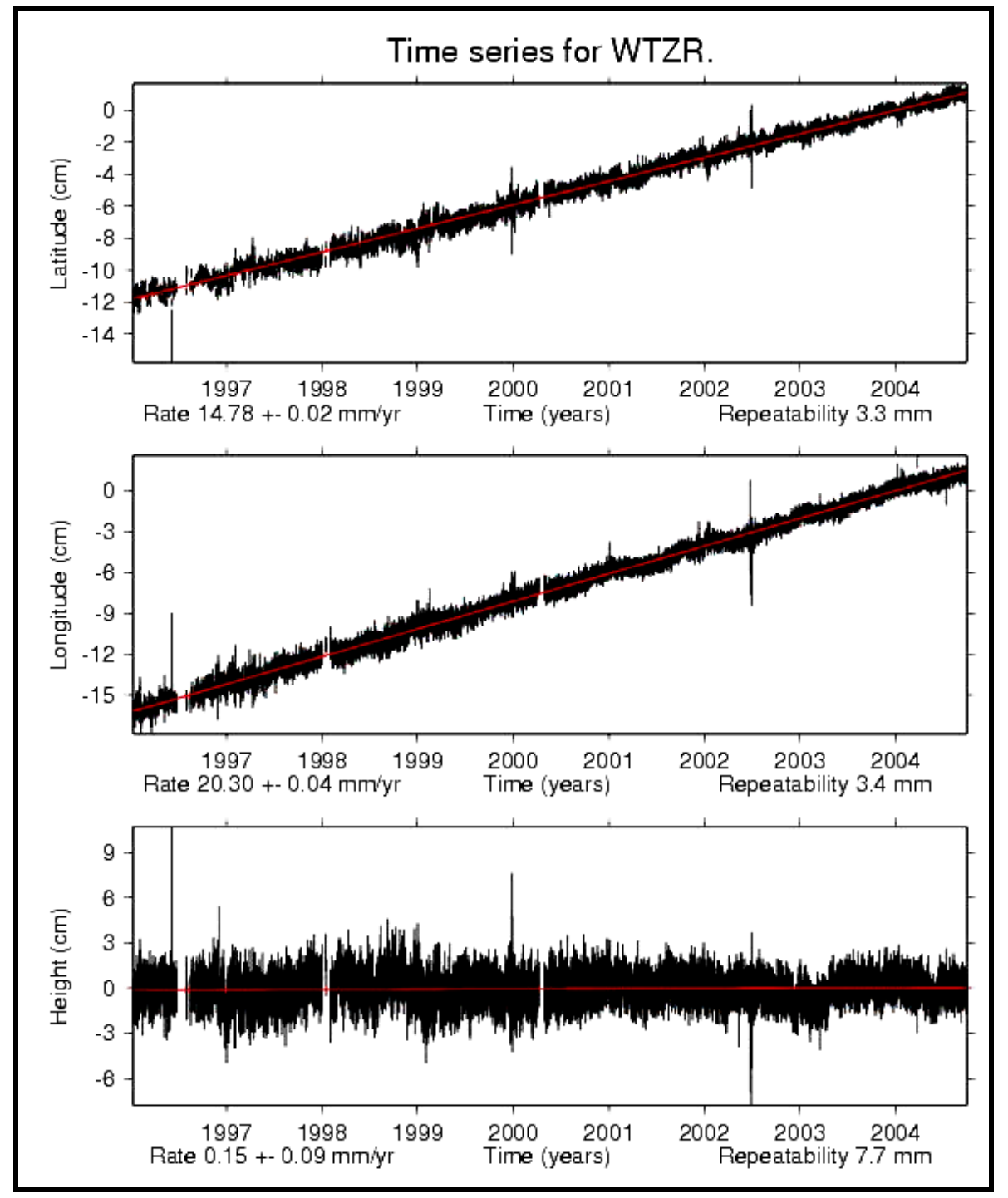

Fig. (20): Time Series for IGS Station Wettzell, Germany (WTZR) 


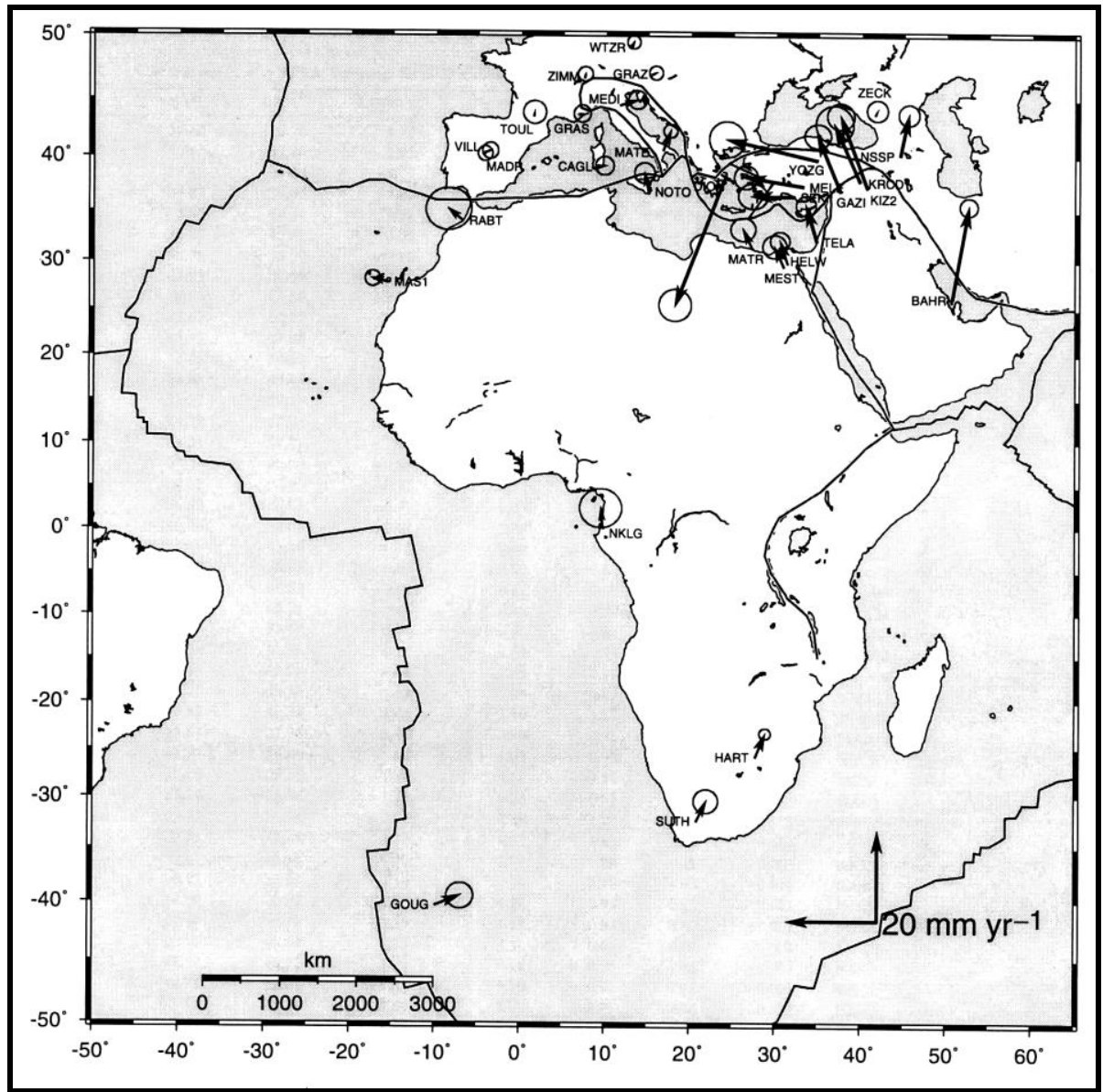

Fig. (21): Shows the chosen Station Matrouh (MATR) and its convenient velocity compared with that of our Egypt-Yemen GPS geodetic Network (After McClusky et al, 2003). 


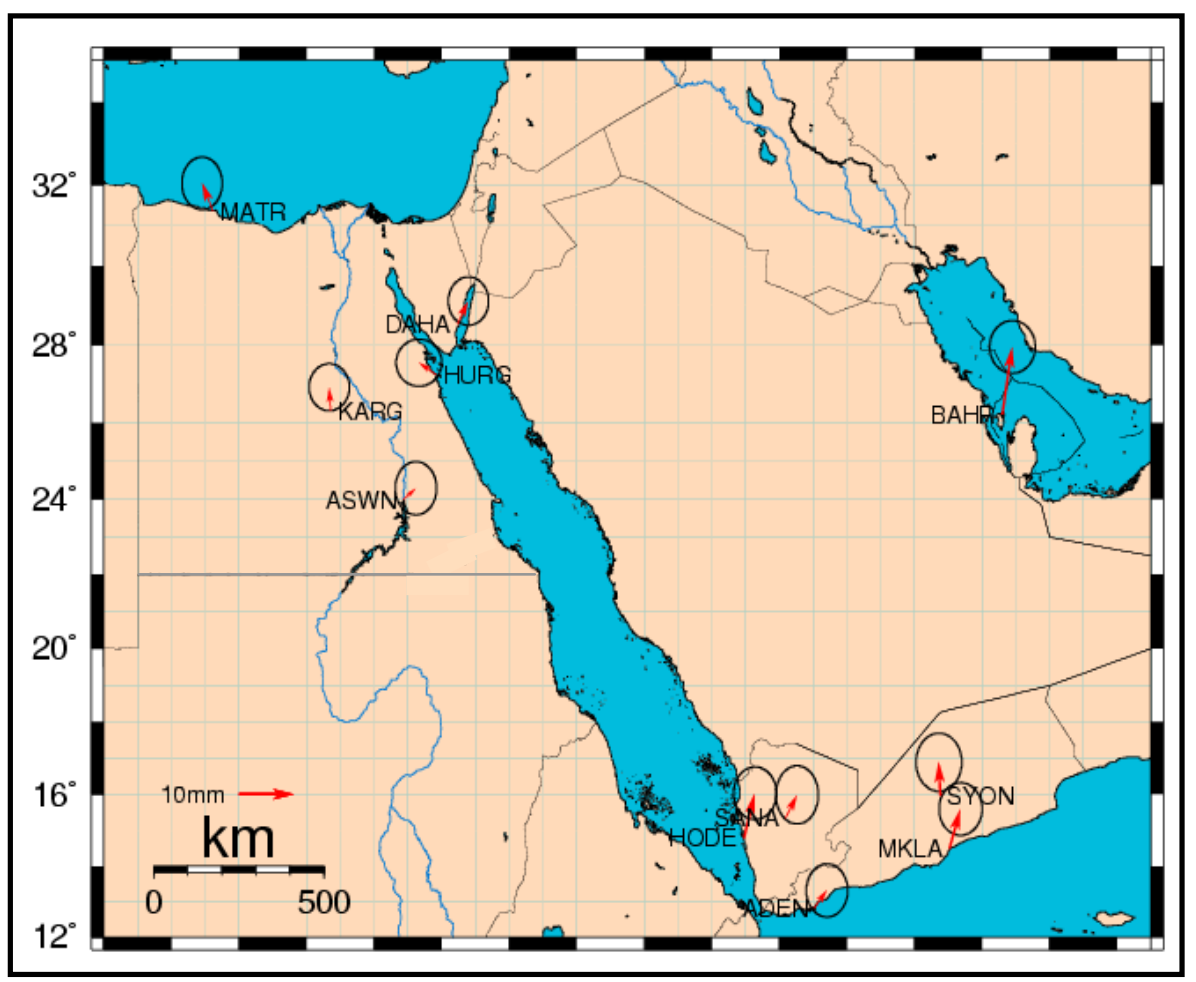

Fig. (22): Shows the general trend of displacements from 2000 to 2003.

\section{Discussion and Conclusions}

The implications of deformation, stress, and earthquake activities in the study area are accomplished through the combined solutions from both GPS and seismological data processing. Beginning of the North East African Margin the seismic activity is clearly shown along the northeastern part of Libya (Cyrenaica) which represent the closest area to the subduction process beneath Hellenic arc. Few larger events are located along the Egyptian coastal shelf. The focal mechanisms of larger events along this margin reflect a transition from a tensional stress to the south of the continental shelf to compressional stress to the south of the subduction zone. 
The spatial distribution of the earthquake hypocenters $(60<\mathrm{h}<300$ $\mathrm{km}$ ) on the Hellenic arc indicates that, the subduction of the African plate under the Eurasian plate took place at an angle of about $30^{\circ}$ and reaches a maximum depth of about $200 \mathrm{~km}$. The focal mechanisms of shallower earthquakes occurred in the convex side of Hellenic arc show a pure reverse faults and reverse faults with strike slip components. The main trend of $\mathrm{P}$-axis is in SW-NE direction. The trend of $\mathrm{T}$-axis for these events takes the same direction of the dipping slab in western Hellenic arc and rotates to become in NW-SE direction in eastern Hellenic arc. The dominant focal mechanisms of the concave side of the arc are normal faulting which is related to the extensional stress field due to the back arc activity behind the arc. The subduction zone in central Cyprus dips to the NNW with an angle about $25^{\circ}-30^{\circ}$ similar to the Hellenic arc. Rotstein and Ben-Avraham (1985) interpreted the deep seismicity in the Gulf of Anatolia to an earlier subduction, which was active prior to the collision of the Anaximander block and continues to be active today. The direction of the P-axis is NW-SE, which is perpendicular to the arc in its eastern and central parts, but oblique to its western part. The two nodal planes are trending NNW- SSE and NE-SW. The stress tensor analysis for the Cyprian Arc earthquakes indicates to NW-SE trending P-axis. Thus, spatial variations in rate and orientation of the Near East Mediterranean, opening of the Red Sea and African Rift against the rigid motions of the adjacent section of the Arabian plates were detected. The aim of study is concentrated to assert the ongoing results of the study region not to be as specific or independent one. The results of GPS Analysis assert the creeping of Africa versus Europe which observed within the period of investigation from 2000 to 2003 to reach about $4.7 \mathrm{~mm} /$ year.

In the Aqaba-Levant Transform fault the activity is trending NNE along the main fault of the Gulf and changed toward the north until Taurus. The activity is diffused in some places due to the intersection of transverse faults with the NNE main trend. From previous focal mechanism solutions along this trend the main trend of T-axis is in $\mathrm{N} 51^{\circ} \mathrm{E}$ and for $\mathrm{P}$-axis is $\mathrm{N} 65^{\circ} \mathrm{W}$. The focal mechanism solutions along 
this trend reflect strike slip faults predominantly with normal components. Few events on the eastern side of the Aqaba Gulf. The stress tensor inversion along the Aqaba Gulf gave stress axes $\sigma_{1}, \sigma_{2}$ and $\sigma_{3}$ trending azimuth/plunge 333/27, 114/56 and 233/18. The overall deformation of the Arabian-Anatolian boundary seems to separate into two components; a left lateral shear which is absorbed on ENE-striking faults and an NW thrusting on either steep or shallow dipping planes.

To the Southern Red Sea and Yemen territories the seismicity seems to be well correlated with the GPS data in the area. The focal mechanism solutions of the events located in the southern Red Sea suggest pure normal faulting mechanism NNE-SSW trending tension axis along the EAR spreading system indicates typical normal faulting mechanism for most parts with an average tension axis oriented NESW reflecting a continental divergent plate boundary. The average direction of the tension axis in the Gulf of Aden is NNE-SSW. such a mechanism reflects a westward extension of the transform fault system and extensional mechanism existing in the Gulf of Aden. The seismic activity along the Sheba Ridge zone is aligned conformably along the main rift axis nearly NWW-SEE. The activity also shows that the rift axis have been transformed by some NE-SW right central strike slip faults. Along the southern part of the Red Sea it is shown two types of faults. The first one from the south indicates normal faulting with large strike-slip components. These solutions have two planes trending NE-SE and NE-SW. The second solution along the southern Red Sea reflects pure normal faulting trending parallel to the Red Sea direction (NW-SE). The general trend of stresses have been evaluated from both the compiled stress field map and the final trend displacement extracted from the GPS data analysis denote to the dominant extensional forces southern of Red Sea and southern borders of Yemen. Some inconsistencies were appeared between GPS relative displacements and seismicity referring to the complex deformation patterns of this region. The spreading velocities parallel to the fracture zone which trends $\mathrm{N} 35^{\circ}$ ranging from $0.9 \mathrm{~cm} /$ year in the west to 1.2 $\mathrm{cm} /$ year in the east and to reach $2 \mathrm{~cm}$ in Bahrain station. These 
velocities show impressive agreement with the epicentral distribution, trending west and joining the African rift zone.

The proposed GPS observations are to use an integrated GPS strategy to determine present-day horizontal motions associated with ongoing tectonic trending in the Near East Mediterranean, northern, central, southern Red Sea till the Yemeni borders; to assert the seismological data analysis. The lack of GPS stations at the costal line of North Egypt were compensated with the extensive seismological data analysis and showed the general trends of stresses and discussed within the previous sections. The efforts must be continued through a strong cooperation between the whole institutions in the study region for evaluating the implications of these temporal changes in plate motions. These broader studies will provide much improved constraints on Africa (Nubia)-Arabia and Africa-Eurasia relative motion and will allow us to determine deformation associated with active rifting. In spite of the greater task of that plan and its ultimate objective, we are optimistic to continue to evaluate the geodynamics of this region of interest.

\section{Acknowledgements}

We would like to express my deepest thanks and gratitude to, Prof. Dr. Matthias Becker and all colleagues in the Institute of Geodesy, University of the Bundeswehr, Munich for the useful suggestions, to the group of IGS GPS Data Centers. Also, gratitude is extended to the board of Generic Mapping Tools (GMT) Software (Wessel et al.).

\section{References}

- Alaydros, A.A., (2003): Seismicity, Tectonics and Crustal Deformation in Red Sea Region; Ph.D. Thesis, Dept. of Geology, Banha Faculty of Science, Zagazig University, Egypt.

- Abou Elenean, K., (1993): Seismotectonics of the Mediterranean region north of Egypt and Libya; M.Sc. thesis, pp. 198, Faculty of Science, Mansoura University, Egypt. 
- Abou Elenean, K.M., (1997): Seismotectonics of Egypt in relation to the Mediterranean and Red seas tectonics. Ph. D. thesis, Fac. Sc. Ain Shams Univ., pp. 200.

- Ambraseys, N., (1978): Middle East; A reappraisal of the seismicity; J. Eng. Geol., 11, pp. 19-32.

- Ben-Avraham, Z., Nur, A. and Cello, G., (1987): Active transcurrent fault system along the north African passive margin; Tectonophys. V. 141, pp.294-260.

- Bosworth, W. and Taviani, M., (1996): Late Quaternary orientation of stress field and extension direction in the southern Gulf of Suez, Egypt: Evidence from uplifted coral terraces

- Buyukasikoglu, S., (1980): Eurasian-African plate boundary in southern Turkey and eastern Mediterranean, in Proceeding of the 7th World Conference on Earthquake Engineering, Geo-Science Aspects, Part 1, Vol. 1, 209-212.

- Korrat, I.M., Ibrahim, E.M., Shrief, R.M. and Abou Elenean, K.M., (1996): Earthquake mechanisms in the Eastern Mediterranean region and their tectonic implications. Bull. IISEE, Vol. 30, 29-44.

- McCusky, S., Reilinger. R., Mahmoud, S., Ben Sari, D. and Tealeb, A., (2003): "GPS Constraint on Africa (Nubia) and Arabia Plate Motions" Journal of Geophysics 155, 126-138.

- Matthias, B. (2002): Personal Contact."universität der bundeswehr München Fkultaet fuer Bauingenieur und Vermessungen -Institut fuer geodaesie.

- Matthias, B.; Carine, B. and Rui F. (On Behalf of the Wegener Diorectory Board) (2002): "Processing And Submission Guidelines For GPS Solutions to be Integrated to A Wegener Data Base"universität der bundeswehr München Fakultaet fuer Bauingenieur und Vermessungen Institut fuer geodaesie.

- McKenzie, D., (1970): Plate tectonics of the Mediterranean region; Nature, 326, pp. 239-243.

- McKenzie, D., (1972): Active tectonics in the Mediterranean region; Geophys., J. R. Astron. Soc., 30, pp. 109-185.

- McKenzie, D., (1978): Active tectonics of the Alpine- Himalayan belt: The Aegean and surrounding regions; Geophys. J. R. Astron. Soc., 55, pp. 217-254.

- Papadopoulos, G.A., Kondopoulou, D.P., Leventakis, G.A. and Pavlides, S.B., 1986: Seismotectonics of the Aegean Region, Tectonophys. V.124, 67-84. 
- Papazachos, B. and Comninakis, P., (1978): Deep structure and tectonics of the eastern.

- Pedone et al., (1992): Mesoscopic fault arrays and borehole breakouts. Tectonics, 15, 4,791-802.

- Bernese GPS Software Operation Manual, (2001): Astronomical Institute University Of Berne, Switzerland. version 4.2

- Rotstein, Y. and Ben-Avraham, Z., 1985: Accretion processes at subduction zones in the eastern Mediterranean; Tectonophys. V. 112, pp. 551-561.

- Said, R., (1990): "The Geology Of Egypt", A. A. Balkema, Rptterdam, Brookfield.

- Salamon, A., Avraham, H., Garfunkel, Z. and Ron, H., 2003: Seismotectonics of Sinai subplate-Eastern Mediterranean Region, Geophys. J. Int. 155, 149-173.

- Schneider, D., (1982): "Complex Crustal Strain Approximation", University Of New Brunswick, Fredericton, N. B. And Institute Of Geodesy And Photogrammetry, Swiss Federal, Institute Of Technology, Zürich. NPPA Ministry of Electricity, Egypt.

- Sofratome Group, (1984): Regional Geology, tectonics and seismology, Chapter 3,21-32

- Trimble, N.L., (1997): "TRIMNET Plus Software's User Manual", Trimble Navigation Limited, Sunnyvale, U.S.A. Angerman D., J. Klotz, C. Reigber, Space-geodetic estimate of the Nazca-South America Euler vector, Earth Planet. Sci. Lett., 171, 329-334, 1999.

* * * $*$

